\title{
CEsifo WORKING

\section{Time in Office and the Changing Gender Gap in Dishonesty: Evidence from Local Politics in India}

Ananish Chaudhuri, Vegard Iversen, Francesca R. Jensenius, Pushkar Maitra 


\section{Impressum:}

CESifo Working Papers

ISSN 2364-1428 (electronic version)

Publisher and distributor: Munich Society for the Promotion of Economic Research - CESifo

$\mathrm{GmbH}$

The international platform of Ludwigs-Maximilians University's Center for Economic Studies and the ifo Institute

Poschingerstr. 5, 81679 Munich, Germany

Telephone +49 (0)89 2180-2740, Telefax+49 (0)89 2180-17845, email office@cesifo.de

Editor: Clemens Fuest

https://www.cesifo.org/en/wp

An electronic version of the paper may be downloaded

- from the SSRN website: www.SSRN.com

- from the RePEc website: $\quad$ www.RePEc.org

- from the CESifo website: https://www.cesifo.org/en/wp 


\title{
Time in Office and the Changing Gender Gap in Dishonesty: Evidence from Local Politics in India
}

\begin{abstract}
Increasing the share of women in politics is regularly promoted as a means of reducing corruption. In this paper, we look for evidence of a gender gap in dishonesty among elected representatives, as well as how this changes with time in office. Based on a sample of 356 inexperienced and experienced local politicians in West Bengal, India, we combine survey data on attitudes towards corruption with data from incentivized experiments. While we find little evidence of a gender gap in the attitudes of inexperienced politicians, a lower faith in political institutions and a greater distaste for corruption can be seen among experienced politicians, particularly women. However, this seeming hardening in attitudes among female politicians also coincides with more dishonest behavior in our experiments. Exploring mechanisms for this difference, we find it to be strongly associated with lower risk aversion. Our study indicates that gender gaps in politics should be theorized as dynamic and changing, rather than static.
\end{abstract}

JEL-Codes: H110, C930.

Keywords: politicians, gender, honesty, die-tossing game, experiments.

Amanish Chaudhuri

University of Auckland / New Zealand

a.chaudhuri@auckland.ac.nz

Francesca R. Jensenius

University of Oslo and Norwegian Institute of

International Affairs / Norway

f.r.jensenius@stv.uio.no
Vegard Iversen

Natural Resources Institute (NRI)

University of Greenwich / United Kingdom

vegard.iversen@gre.ac.uk

Pushkar Maitra

Monash University

Victoria / Australia

pushkar.maitra@monash.edu.au

March 18, 2020

We gratefully acknowledge funding from the University of Auckland, Monash University, and the Norwegian Research Council (project number 250753). IRB clearance obtained from University of Auckland (Approval number 019938). We thank the field staff at Outline India for conducting the surveys and experiments that we report from. 
The under-representation of women in political life has galvanized efforts to ensure that more women stand for and win elections. Some 118 countries have so far introduced quotas or quota-like arrangements, resulting in a steady rise in the share of women elected for office (Dahlerup et al., 2014). Arguments in favor of an increased political presence for women include notions of fairness and social justice; that women's experiences and perspectives are distinct, valuable and deserve to be heard; and that women, as well as other under-represented groups, can serve as role models (Phillips, 1995, Wangnerud, 2009, Campbell et al., 2010). Increased female representation has also been found to shift policy agenda and development outcomes (see, for example, Lovenduski, 1986, Skjeie, 1991, Lovenduski and Norris, 1993, Chattopadhyay and Duflo, 2004a,b, Duflo and Topalova, 2004, Clots-Figueras, 2005, Dahlerup, 2006, Krook, 2006, Rehavi, 2007, Svaleryd, 2009, Raabe et al., 2009). ${ }^{1}$

Another commonly encountered argument is that increasing the share of women in politics may improve governance and reduce corruption, with research suggesting that women are more trustworthy (Dollar et al., 2001, King and Matland, 2003, Schneider and Bos, 2014, Barnes and Beaulieu, 2019), more averse to risk taking (Croson and Gneezy, 2009, Eckel and Grossman, 2002, Roszkowski and Grable, 2005, Fletschner et al., 2010), and lack the political networks required to engage in malfeasance (Heath et al., 2005, Goetz, 2007, Ban and Rao, 2008, Bjarnegård, 2013, O’Brien, 2015). ${ }^{2}$

Cross-country and cross-regional evidence suggests that having a higher share of women in parliament or in the bureaucracy is associated with less corruption (Dollar et al., 2001, Grimes and Wängnerud, 2010, Jha and Sarangi, 2018). Studies using individual-level data have also found women to be more honest and less tolerant of corruption (Friesen and Gangadharan, 2012). In India, for example, Duflo and Topalova (2004) report that villagers are less likely to pay bribes if the village headship of the village is reserved for women, while Baskaran et al. (2018) find that the annual rate of asset accumulation among female legislative assemblies members is 10 per cent points lower than for men. Brollo and Troiano (2016) report that female mayors in Brazil are less likely to be involved in administrative irregularities. Other studies, however, find no gender disparity in the propensity to be corrupt or dishonest (Sung, 2003, Vijayalakshmi, 2008, Alatas et al., 2009, Debski et al., 2018). ${ }^{3}$ Some scholars have tried to reconcile these seemingly contradictory research findings by suggesting that the gender gap

\footnotetext{
${ }^{1}$ Including more women can also increase the quality of politicians. A recent study using in-depth Swedish data found women to enter politics at the expense of "mediocre" men-with female politicians crowding out the least-qualified among male office holders (Besley et al., 2017).

${ }^{2}$ Barnes and Beaulieu (2019) find that while men typically believe that women are more honest and risk averse, women are more likely to believe that their networks are different.

${ }^{3}$ For example, Sung (2003) shows that the impact of gender on corruption reduces considerably once variables such as rule of law, freedom of press, and democracy are controlled for. Put differently, the negative correlation between women's representation and corruption may simply reflect that high quality institutions are likely to have less corruption and more gender equality at the outset.
} 
in honesty is more pronounced in industrialized countries (Alatas et al., 2009, Esarey and Schwindt-Bayer, 2018).

An understudied aspect of gender and dishonest behavior, is how time in office affects politicians' attitudes and behaviors. ${ }^{4}$ In this paper, we explore the changing, or dynamic, nature of the governance gender gap by asking the following questions: Are newly elected women similarly likely to engage in corrupt behavior as men? Do the attitudes and behaviors of women and men transmute differently during their time in office? How can such changes and gender differences be explained? Answering these questions is difficult due to the limited means of studying elected politicians. Studies using experimental designs or behavioral games typically rely on citizen participants (often university students from industrialized countries), which limits the scope for extrapolating findings to elected politicians. This is important because the observable and unobservable characteristics and attitudes of politicians tend to be different from the general citizenry. Research on real-world politicians, on the other hand, often resorts to proxies and indirect measures when attempting to capture politicians' intentions and behavior, such as the quality of program delivery in their constituency or aggregate regional/country-level indicators of corruption. In this paper, we have avoided this pitfall by gathering two types of data from a sample of 356 local politicians in West Bengal, India. First, we conducted an extensive survey of attitudes towards corruption and trust in political institutions. While informative, attitudinal data are prone to self-reporting and social-desirability biases. To alleviate such concerns, data were also gathered from incentivized experiments.

To measure dishonest behavior, we use an experiment in which participants are asked to throw a die thirty times in private, with payment received based on the number of sixes they report (see Fischbacher and Föllmi-Heusi, 2013). ${ }^{5}$ Further, to probe possible mechanisms behind gender differences in dishonest behavior, we examine the behavior of participants in a dictator game (to elicit notions of altruism), a trust game (which captures individuals' pre-disposition to behave in a trusting and/or trustworthy manner) and an investment game (measuring risk attitudes). ${ }^{6}$

Two main findings arise. First, whereas we find little overall difference in attitudes towards corruption among male and female politicians in the self-reported survey data, the experienced politicians in our sample express markedly more intolerance towards corruption-particularly

\footnotetext{
${ }^{4}$ Previous literature has shown that the gaining of political experience by women can improve governance. For example, in terms of village councils with women heads elected into reserved seats, Afridi et al. (2017) find more administrative lapses and program leakages occur during their first year in office, but not thereafter.

${ }^{5}$ Given there is no monitoring of the actual number of sixes reported, we cannot know for certain whether an individual actually cheats or not. We can, however, use the deviation of the actual number of sixes reported from the theoretical distribution anticipated in order to obtain a measure of dishonesty. Variants of this task have been used to study dishonest behavior, including in India. See, for example, Hanna and Wang (2016) and Kröll and Rustagi (2016).

${ }^{6}$ We also administered an ultimatum game and a public goods game with a punishment option. As these are not immediately relevant to this paper, they are not reported on here.
} 
the women. ${ }^{7}$ In contrast, the experimental data reveals a gender gap in behavior. Among inexperienced politicians, women report fewer sixes than men (though this difference is not statistically significant). However, among experienced politicians, women report more sixes than men, and the difference between inexperienced and experienced female politicians is statistically significant. There is no observable difference between experienced and inexperienced male politicians. These findings indicate a pronounced time-in-office effect on dishonest behavior among female, but not among male, politicians.

Three possible mechanisms are considered in attempting to explain these differences between inexperienced and experienced politicians: pro-sociality (altruism and/or trustworthiness), risk aversion, and differences in political aspirations. We find no support for the hypothesis that the increase in women's dishonesty is a result of them becoming less altruistic than men, or from gender differences in aspirations for future political office. However, we find strong evidence for women being more risk averse than men when taking office, and for experienced female politicians being significantly less risk averse than their inexperienced counterparts. There is no evidence of a similar difference between inexperienced and experienced men.

Our study contributes to the literature in several ways. To the best of our knowledge, it is the first to measure both self-reported attitudes and experimental behavior in a large sample of elected politicians. ${ }^{8}$ Further, by comparing inexperienced and experienced politicians, we present evidence on how behavior may change with time in office and exposure to specific political environments. Our finding that the behaviors of inexperienced and experienced politicians differ - and that considerable change appears to occur after as little as one term in office - provides valuable insight into the possible speed of behavioral change, and may also help reconcile some of the seemingly contradictory conclusions about a gender gap in dishonesty in other studies. Finally, our finding that risk aversion is negatively associated with dishonest behavior, and that women appear to become less risk averse with time in office, adds nuance to the growing consensus that accountability mechanisms are key to reducing corrupt behavior. Crucially, the behavioral differences we observe suggests that the deterrence effect of potentially being caught for malfeasance is not fixed, but will decline as newly elected politicians become more experienced.

\footnotetext{
${ }^{7}$ This discrepancy between attitudes and behavior is consistent with other work comparing survey and experimental data, and serves as a reminder not to read too much into self-reported survey data (see Chaudhuri, 2012).

${ }^{8}$ Survey experiments using actual legislators have become more common in political science in recent years, see Naurin and Öhberg (2019).
} 


\section{The gender gap in dishonest behavior}

Following the publication of Dollar et al.'s (2001) and Swamy et al.'s (2001) cross-country analyses suggesting that having more women in parliament and other leadership positions reduces corruption, an emphasis on the instrumental value of women in positions of power has spread widely. This has been reiterated in World Bank reports (see, for example, WB, 2002) and policy debates across the world, with governments acting swiftly on the idea that women can help clean up politics. In 2003, for example, Mexico's customs service announced that its new anti-corruption force would be entirely female, while in Uganda, the vast majority of positions as local government treasurers are assigned to women. ${ }^{9}$

A variety of explanations as to why women may be less prone to corrupt or dishonest behavior in office have been proposed, ${ }^{10}$ one being that men and women are socialized to behave differently. In most contexts, men and women live very different lives, have different jobs and caring responsibilities, and face drastically different social expectations. The result is that women in general, and perhaps also women politicians, tend to be more pro-social than men. ${ }^{11}$ Evidence from dictator games suggests that women are more generous (Eckel and Grossman, 1998), while trust games show that, by and large, men are more trusting and women more trustworthy (see Rau, 2012, for a survey). Many observational and experimental studies support this argument. Dreber and Johannesson's (2008) experiment in Sweden shows women are less likely than men to lie in order to obtain a higher payoff, while D'Attoma et al. (2017, p. 2) conclude that women appear to be much more tax compliant than men "in every country and under every condition." Similarly, a meta-analysis of sixty-three experimental studies finds that women to appear to exhibit greater propensities to tell the truth (Rosenbaum et al., 2014). We refer to this as the "pro-social mechanism." 12

A second explanation, also with ample empirical support, is that women tend to be more risk averse than men. We refer to this as the "risk aversion mechanism." Data from the US show that, as wealth increases, the proportion of wealth held as risky assets is higher among

\footnotetext{
${ }^{9}$ Examples are from Goetz (2007).

${ }^{10}$ We do not equate corruption with dishonest behavior, but draw on literature examining various incentivized experiments. We expect those who behave more dishonestly in incentivized experiments to be more prone to corruption behavior when given the opportunity, as has been shown by Hanna and Wang (2016) and Kröll and Rustagi (2016).

${ }^{11} \mathrm{We}$ focus here on differences in experiences and socialization rather than in structural differences that hamper women's entry into office, such as differences in access to networks (Heath et al., 2005, Goetz, 2007, Bjarnegård, 2013, O'Brien, 2015). Essentialist versions of this argument have met with strong resistance from feminist scholars (see, e.g., Phillips, 1995, Goetz, 2007).

${ }^{12}$ Chaudhuri's (2012) comprehensive review of laboratory experimental evidence on gender differences in corruption concludes that either women behave less dishonestly than men or there are no significant gender differences. No studies of corruption find men to be more pro-social. Lambsdorff and Boehm (2011), in their survey of the literature on gender and corruption, suggest that caution should be shown when interpreting findings. In one-shot transactions, women are less likely to strike corrupt deals, pointing to improved honesty and governance. However, as transactions are repeated, women's willingness to engage in corrupt behavior echoes that of men.
} 
men than among women (Jianakoplos and Bernasek, 1998). Further, in behavioral games with gambling options, men are more likely to choose risky bets (Levin et al., 1988). In their review of gender differences in economic experiments, Croson and Gneezy (2009) conclude that there are robust differences in male and female risk preferences. Applying these insights to a context of corruption, Schulze and Frank (2003) show that while women are as willing as men to accept bribes in a no-risk situation, they are less willing to do so in higher risk situations. ${ }^{13}$

A third possible explanation relates to gender differences in aspirations for a future role in politics, ${ }^{14}$ with politicians tending to be more opportunistic when they have a shorter time horizon in office. Ferraz and Finan (2011) argue that political leaders with lower re-election prospects are more likely to be corrupt. In the Indian context, women politicians (who are often elected in reserved seats) are viewed as being less able (Beaman et al., 2009) and are therefore unlikely to be re-elected once reservation is withdrawn. ${ }^{15}$ Additionally, many female politicians in India face resistance from their families when they run for office, get less credit for the work they do, and experience negative attention and sexual harassment once in office (see Jensenius, 2019). Thus, women may find it less attractive to remain in politics for a long time. Given the political aspirations of women are likely to be lower than those of men, it may be that women are more attracted to short-term gains from office. We refer to this as the "aspiration mechanism."

Since the pro-social behavior, risk aversion and aspirations of men and women can be attributed to socialization outside of politics, it should not be surprising to observe differences in the attitudes and behavior of male and female politicians at the time of entering office: we should expect women to be less prone to dishonesty when entering political office. Crucially for our purposes, however, participation in politics may re-socialize politicians - changing how pro-social and risk averse they are, as well as their aspirations for a political career. Being an elected representative is a job, but also a special job: a female newcomer's ability to perform and her attitudes to the tasks and responsibilities that come with holding office are likely to be shaped by her local political environment. Newly elected politicians are thus likely - for better or worse - to be socialized into the local version of the political game. Research from Zambia, for instance, shows that holding office increases politicians' adherence to a reciprocity norm, indicating that with experience comes a greater likelihood of engaging in corrupt behavior

\footnotetext{
${ }^{13}$ This risk-aversion mechanism implies that women politicians are less likely to behave corruptly in environments with greater electoral accountability and therefore a higher risk of being caught for malfeasance. This is consistent with the patterns established by Esarey and Schwindt-Bayer (2018) in their study of time-series cross-sectional data from seventy-six democratic-leaning countries. Alatas et al. (2009) also show that while women are less tolerant of corruption than men in Australia, no such gender gap is found in India, Indonesia or Singapore. However, they argue that this is because women's views on social issues may be more influenced by men in patriarchal countries, where male views tend to be more dominant.

${ }^{14}$ Wasserman (2020), using a regression discontinuity design, finds that losing an election induces substantially more attrition among female candidates than male.

${ }^{15}$ More than 92 per cent of experienced and 88 per cent of inexperienced women politicians are elected in reserved seats; with the corresponding figures for men being 72.6 per cent and 74.7 per cent respectively.
} 
(Enemark et al., 2016). Thus, it should be expected that any gender gap in attitudes and behavior relating to dishonesty among new political entrants will change over time. As holding political office exposes men and women to the same environment, it follows that their attitudes and behavior are likely to become more similar over time. These are the ideas we test in the following sections.

\section{Context and data}

Our data are from West Bengal, a large state in Eastern India. India is a classic example of a developing country where it is expected that politicians will engage in corrupt behavior, with the country's media regularly reporting on scams and corruption scandals. Additionally, according to Transparency International's 2018 Corruption Perceptions Survey, 56 per cent of Indians reported paying bribes for services in the previous year. Credible empirical evidence points to widespread political corruption. A large share of politicians enter politics through their connections to political families (Chandra, 2016). Of those elected to parliament in 2014, some 34 per cent had criminal cases pending, 21 per cent of which involved heinous crimes (Vaishnav, 2017). Evidence suggests that bribe-paying is widespread and may be increasing (Borooah, 2016). Studies of the sworn affidavits politicians must submit before running for office show that many members of legislative assemblies accumulate sizable wealth during their time in office (Bhavnani, 2012, Fisman et al., 2014).

India is a parliamentary democracy with elections to the lower house of the national parliament and to state assemblies following a first-past-the-post system. The $73^{\text {rd }}$ Amendment to the Constitution, ratified in April 1993, established and codified a three-tiered system of local governance (known as the panchayat system), comprising councils at the village, block (or sub-district), and district levels. While the panchayat system had existed in many Indian states since the 1950s, it was not until the mid-1990s that elections began taking place regularly and village councils started playing more than a limited role. West Bengal was an exception. When the Marxist CPI(M)-led Left Front government came to power in West Bengal in 1977 on a platform of agrarian and political reforms, revitalizing the panchayat system became a key priority. The first panchayat election took place in 1978, with elections held every five years since then. Thus, the decentralization mandated by the Amendment was already well established in West Bengal (see, Bhattacharya, 2002, Ghatak and Ghatak, 2002, Bhattacharya, 2012). However, a novel and radical feature of the 1990s panchayat reforms was the mandated political reservations for minority groups and women. Regarding women's representation, the minimum share was set at one-third. West Bengal implemented this quota in 1993, and then increased it to 50 per cent from the 2013 elections onwards.

The village council (or gram panchayat, henceforth GP) is the lowest tier of local governance. GP sizes, in terms of number of villages and residents, vary across states. In West 
Bengal, each GP covers between five and fifteen villages, representing a total population of around 10,000 people. Each GP has an elected council headed by a pradhan. ${ }^{16}$ In West Bengal, a candidate for a GP ward seat may be nominated by a political party or stand as an independent candidate. In either case, though, he/she must be a resident of the village they represent. ${ }^{17}$ The GP is responsible for allocating funds to administrative expenses such as salaries, and the provision and maintenance of local public goods. Examples of the latter include roads and irrigation canals, village-level sanitation services, and the delivery of important public programs. ${ }^{18}$ GP councilors therefore have considerable local power, meaning any corrupt or dishonest behavior can adversely affect vulnerable sections of society.

West Bengal is characterized by intense political competition at every tier of government. All recent elections, GP elections included, have witnessed intense rivalry between two partiesthe CPI(M) (leading the Left Front, LF) and the All India Trinamool Congress (AITC) - both of which use local cadres to mobilize voters. From 1977 to 2011, the LF government was in power at the state level, as well as being dominant in local-level elections. The state legislative assembly elections in 2011 saw a massive political change, with AITC taking over as the ruling party. In the 2013 local elections, AITC also won large majorities at the GP level across the state, going on to retain control of most village councils in the 2018 elections.

\subsection{Study design}

Our study participants are 400 GP-level politicians from thirty randomly selected GPs in eleven blocks (sub-districts) in North 24 Parganas district (see Figure 1). West Bengal has twenty-three districts and a population of approximately 90 million, of which 11 million live in North 24 Parganas district. At present, there are approximately 3,000 GPs in the state. with panchayat members typically numbering between twenty and thirty. The eleven blocks covered by this study are Amdanga (1), Barasat-I (1), Barasat-II (1), Basirhat-I (5), Basirhat-II (7), Deganga (2), Gaighata (5), Habra-I (3), Habra-II (2), Hingalganj (2) and Sandeshkhali-I (1). ${ }^{19}$ Blocks were randomly selected prior to data collection, with between eight and twelve elected politicians sampled from each GP. The list of politicians from each panchayat was also generated randomly from data available from the Election Commission of India. The selected politicians were contacted either through the GP's pradhan - the new one if available or the

\footnotetext{
${ }^{16}$ The pradhan is the only council member of the council with a full-time appointment, and is typically the person vested with most power within a council (Kanango, 1998, Chattopadhyay and Duflo, 2004a,b). Eligible voters can either directly elect the pradhan (in most states) or let the council elect the pradhan from among its members (in Karnataka, Kerala, Maharashtra and West Bengal).

${ }^{17}$ Whether candidates can be nominated by political parties varies across India's states. For example, whereas in West Bengal candidates can be nominated by political parties, in Uttar Pradesh candidates cannot disclose their political affiliations.

${ }^{18} \mathrm{GP}$ revenue comes mostly in the form of central and state governments grants, but they can also generate some revenue through tax collection. The latter includes water, property and trade taxes, as well as (to a lesser extent) revenue from fees and rental income.

${ }^{19}$ The numbers in parentheses indicate the number of GPs canvassed within each of these eleven blocks
} 
old one if not - or via the Block Development Office, the government body with authority over the workings of the GP. The survey and experiments were implemented in September-October 2018, roughly three months after the 2018 panchayat elections. Due to political violence and opposition parties contesting the validity of the polls in some GPs, official election results were not declared until September 2018. Incoming politicians had not, therefore, taken over GP administration at the time of our survey. Accordingly, in terms of our study, the politicians elected to office for the first time can be considered truly inexperienced, in the sense that they had not even yet attended the orientation sessions that form part of the induction process. ${ }^{20}$ Figure 2 presents the proportion of GP seats held by each of the main parties in North 24 Parganas. Note that while the AITC has the largest number of elected GP politicians in both 2013 and 2018, the latter election witnessed a sizable reduction in the proportion of seats won by the Left Front and a corresponding increase in the proportion of seats won by "others." 21

\section{Figure 1: Location of our study}
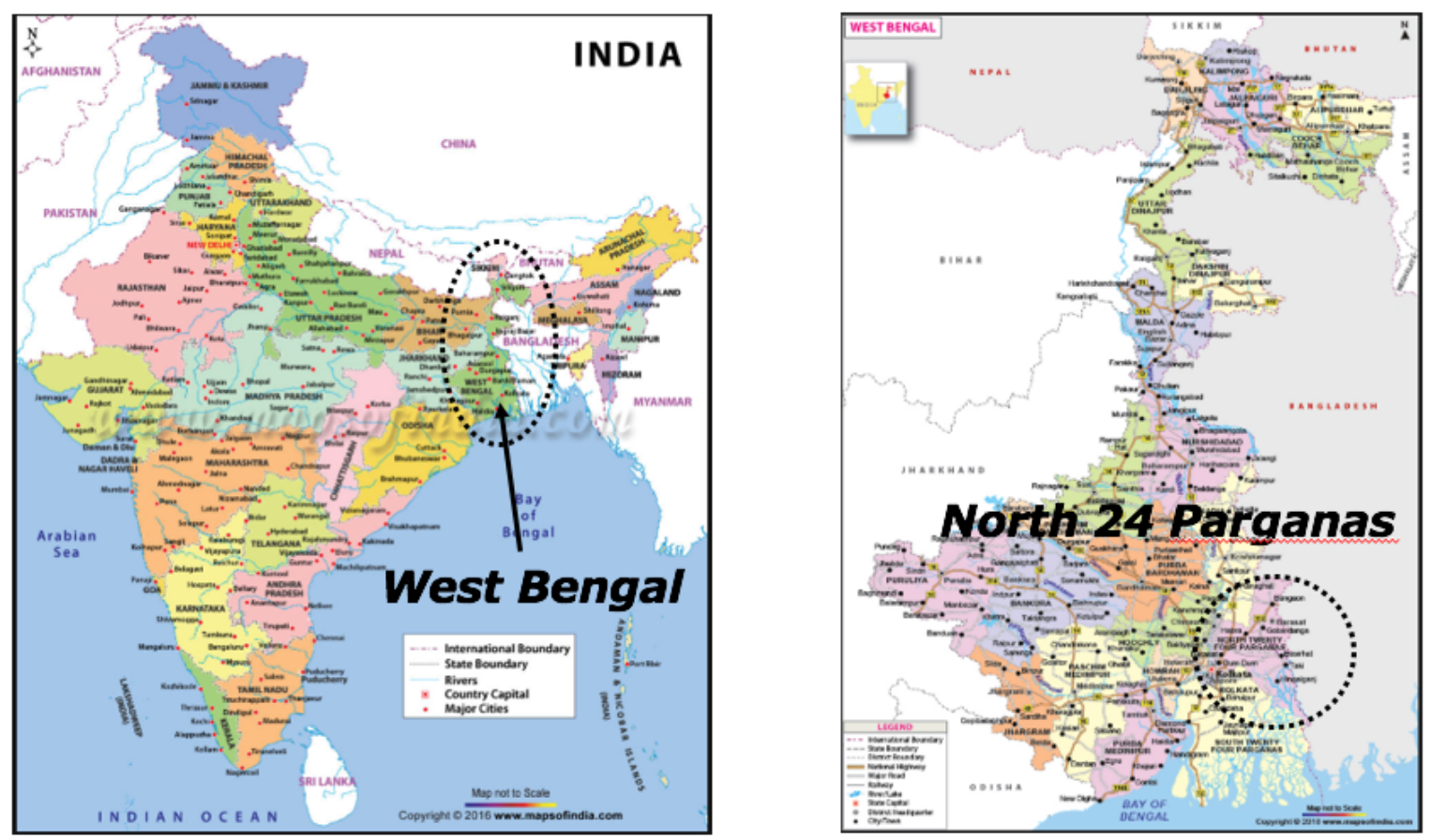

To facilitate comparison of experienced and inexperienced politicians in as similar a context as possible, we approached both incoming (newly elected and re-elected) and outgoing (lost or rotated out out due to reservations, but having held elected positions in the past five or more years) politicians in the sampled locations. Among the 400 politicians, 239 were incoming

\footnotetext{
${ }^{20}$ A randomly chosen sample of 100 ordinary citizens - without political experience and residing in the same GPs - also participated in the surveys and experiments. For the purposes of this paper, we do not include this citizen sample.

${ }^{21}$ This includes India's governing party, the India Bharatiya Janata Party (BJP), and independents.
} 
Figure 2: Proportion of GP seats by party: 2013 and 2018

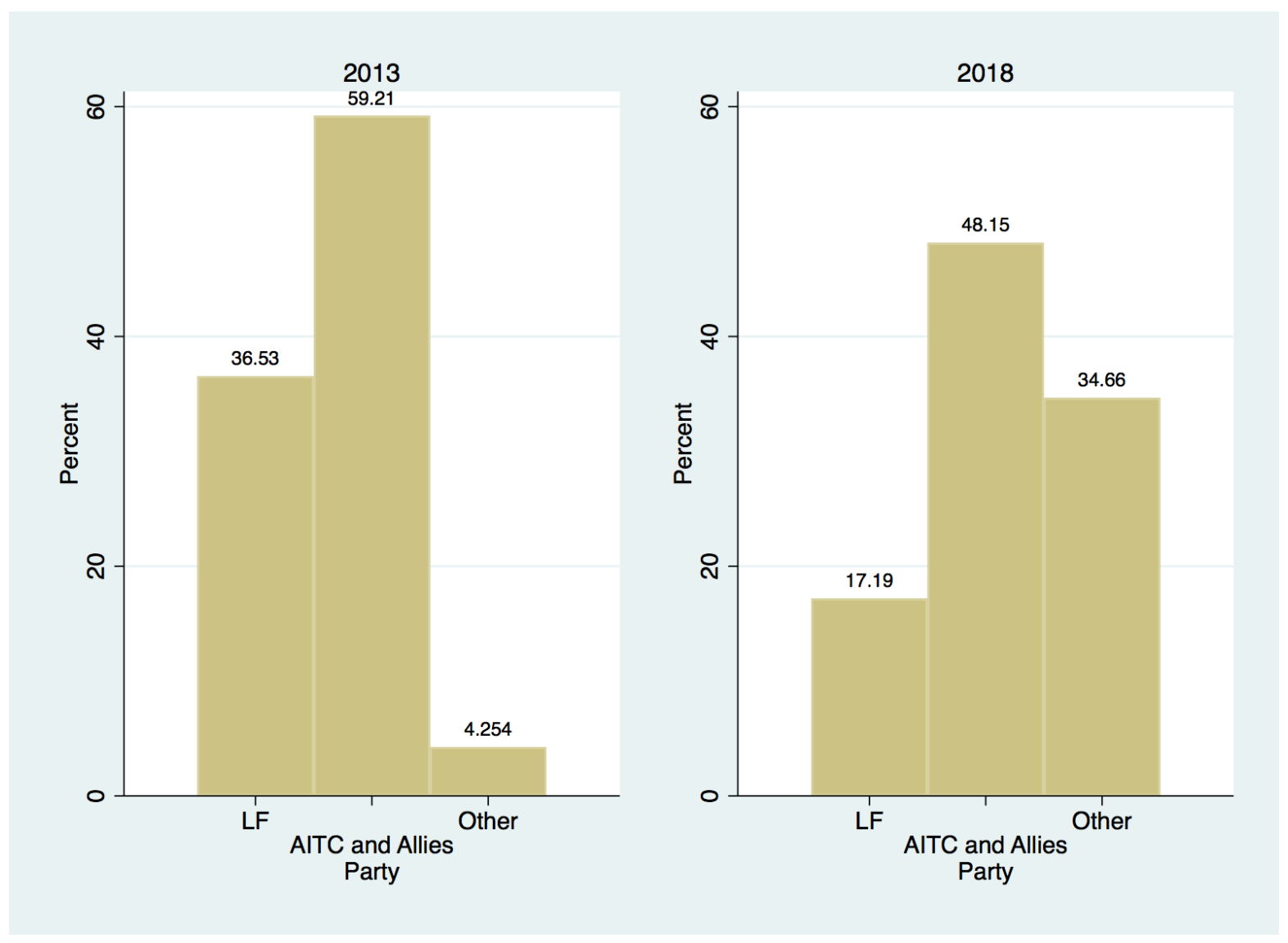

Notes: Authors' computation using data available from the State Election Commission, Government of West Bengal. Sample restricted to the district of North 24 Parganas. AITC and Allies includes AITC and Indian National Congress (INC). Other include a range of parties including Bharatiya Janata Party (BJP) and independents.

(i.e. elected to the GP council in 2018), with the remaining 161 outgoing. Though some among the incoming politicians had some prior political experience, a large majority had no such experience. Given that first-time elected and re-elected politicians are not directly comparable, we excluded from our analysis 44 incoming politicians who had prior political experience either as pradhan, deputy pradhan, ward member or ward convener. Our primary estimating sample thus consists of 356 GP councilors: 195 inexperienced politicians and 161 experienced politicians, elected in the same localities. ${ }^{22}$ Our sample of inexperienced politicians consists of 111 women and 84 men, while our sample of experienced politicians consists of 78 women and 83 men.

In the first part of the study, each participant responded to an extensive survey including

\footnotetext{
${ }^{22}$ Our findings are robust to including the 44 experienced incoming politicians in the group of experienced politicians.
} 
Table 1: Descriptive statistics on observables

\begin{tabular}{|c|c|c|c|c|c|c|c|c|}
\hline & \multicolumn{4}{|c|}{ Female } & \multicolumn{4}{|c|}{ Male } \\
\hline & \multicolumn{2}{|c|}{ Inexperienced } & \multicolumn{2}{|c|}{ Experienced } & \multicolumn{2}{|c|}{ Inexperienced } & \multicolumn{2}{|c|}{ Experienced } \\
\hline & $\begin{array}{c}\text { Mean } \\
(1)\end{array}$ & $\begin{array}{l}\text { SE } \\
(2)\end{array}$ & $\begin{array}{c}\text { Mean } \\
\text { (3) }\end{array}$ & $\begin{array}{l}\text { SE } \\
(4)\end{array}$ & $\begin{array}{c}\text { Mean } \\
(5)\end{array}$ & $\begin{array}{l}\mathrm{SE} \\
(6)\end{array}$ & $\begin{array}{l}\text { Mean } \\
(7)\end{array}$ & $\begin{array}{l}\text { SE } \\
(8)\end{array}$ \\
\hline Years of Schooling 6-10 & 0.613 & 0.046 & 0.590 & 0.056 & 0.500 & 0.055 & 0.373 & 0.053 \\
\hline Years of Schooling $>10$ & 0.288 & 0.043 & 0.356 & 0.055 & 0.381 & 0.053 & 0.578 & 0.055 \\
\hline Age & 35.838 & 0.756 & 39.615 & 0.932 & 42.393 & 1.109 & 48.542 & 1.096 \\
\hline Hindu General Caste & 0.117 & 0.031 & 0.167 & 0.042 & 0.083 & 0.030 & 0.157 & 0.040 \\
\hline Hindu OBC & 0.117 & 0.031 & 0.090 & 0.033 & 0.071 & 0.028 & 0.157 & 0.040 \\
\hline Hindu SC/ST & 0.378 & 0.046 & 0.449 & 0.057 & 0.238 & 0.047 & 0.277 & 0.049 \\
\hline Non Hindu & 0.387 & 0.046 & 0.295 & 0.052 & 0.607 & 0.054 & 0.410 & 0.054 \\
\hline Land owned (Katha) & 15.622 & 3.563 & 12.179 & 2.716 & 44.190 & 9.117 & 49.386 & 7.243 \\
\hline Self-employed Farming & 0.000 & 0.000 & 0.026 & 0.018 & 0.226 & 0.046 & 0.398 & 0.054 \\
\hline Self-employed Non-Farming & 0.045 & 0.020 & 0.064 & 0.028 & 0.500 & 0.055 & 0.325 & 0.052 \\
\hline Domestic Duties & 0.568 & 0.047 & 0.679 & 0.053 & 0.000 & 0.000 & 0.000 & 0.000 \\
\hline Total Leaders in Family & 0.378 & 0.071 & 0.356 & 0.068 & 0.369 & 0.097 & 0.265 & 0.089 \\
\hline Elected in a Reserved Seat & 0.883 & 0.031 & 0.923 & 0.030 & 0.726 & 0.049 & 0.747 & 0.048 \\
\hline No Prior Leadership Exp & 0.955 & 0.020 & 0.436 & 0.057 & 0.905 & 0.032 & 0.361 & 0.053 \\
\hline Affiliation AITC & 0.937 & 0.023 & 0.667 & 0.054 & 0.917 & 0.030 & 0.602 & 0.054 \\
\hline Affiliation Independent & 0.018 & 0.013 & 0.051 & 0.025 & 0.012 & 0.012 & 0.096 & 0.033 \\
\hline Affiliation Left Front & 0.009 & 0.009 & 0.256 & 0.050 & 0.024 & 0.017 & 0.265 & 0.049 \\
\hline Sample Size & 111 & & 78 & & 84 & & 83 & \\
\hline
\end{tabular}

Notes: Sample includes inexperienced incoming politicians and experienced outgoing politicians. The omitted category for party affiliation is affiliation other parties (including Indian National Congress and Bharatiya Janata Party).

questions about their political work and attitudes. The questions we focus on here relate to corruption and trust in political institutions. Having completed the survey, each respondent participated in a set of behavioral games involving incentivized choices attached to monetary rewards. These experimental tasks were conducted in the same order for all respondents, in a private setting. To avoid potential wealth effects in decision-making, participants were not given information about how much they had earned from the tasks until all of them had been completed. Following the elicitation of decisions, we decided randomly whether to reward each participant for the first- or second-mover decision. We also randomly matched respondents $e x$ post to determine their payoffs, which were handed over to respondents within a stipulated time-frame (typically the next day).

Table 1 presents the means and standard errors of politician characteristics in the four main subsamples (male and female, inexperienced and experienced). Consistent with other studies in India (e.g., Chattopadhyay and Duflo, 2004b, Afridi et al., 2017), female politicians are younger than their male counterparts, with the average female-male age difference for inexperienced and experienced politicians being seven and nine years, respectively. Regarding education, 58 per cent of experienced males and 36 per cent of experienced females have completed more than ten years of schooling, while among inexperienced politicians the 
corresponding percentages are 38 per cent and 29 per cent. Turning to land ownership, the households of experienced males own an average number of 49 kathas of land, compared to 12 for experienced females. The corresponding figures for inexperienced males and females is, respectively, 44 and $16 .^{23}$ The average number of individuals with political leadership experience within the family ranges from 0.27 for experienced males to 0.38 for inexperienced females. This differs notably from higher-level politics in India, where a much larger share of women than men have dynastic ties (Basu, 2016). There are some, but mostly minor, differences in caste composition. Table 1 also presents information about political or other civil society leadership experience, the reservation status of the seat the respondent was elected into, and party affiliation. Unsurprisingly, inexperienced female politicians are more likely to report no prior civil society leadership experience. ${ }^{24}$ The number of inexperienced politicians reporting affiliation to AITC rather than the Left Front can be seen to be proportionately much larger than for experienced politicians. This reflects the change in the strength of these parties in the district, as shown in Figure 2. These differences in the characteristics of incoming and outgoing politicians are important confounders which we control for in our multivariate regression analyses.

\section{Attitudes and behavior}

\subsection{Attitudes towards corrupt behavior elicited via surveys}

Our survey questions facilitate scrutiny of self-reported attitudes to nepotism and corrupt acts by politicians, civil servants and members of the public. To capture these attitudes, respondents were presented with the following statements. ${ }^{25}$

1. It is ok for a shopkeeper to offer a politician a small gift to help keep the tax auditor away.

2. It is ok for a businessman to give a job in a family firm to a family member even though other applicants are more qualified.

3. It is ok for a government employee to give a government job to a family member even though other applicants are more qualified.

4. It is ok for a male politician to give a government job to a family member even though other applicants are more qualified.

5. It is ok for a female politician to give a government job to a family member even though other applicants are more qualified.

\footnotetext{
${ }^{23}$ Katha is a local measure of land area. In West Bengal, 1 katha $=720$ square feet.

${ }^{24}$ This includes leadership in self-help groups or senior management positions in community-level organizations.

${ }^{25}$ This design of vignette-type examples draws on Truex (2011).
} 
6. It is ok for a government employee to ask a school teacher for a small gift in exchange for approving his BPL card without proper documentation.

7. It is ok for a politician to ask a school teacher for a small gift in exchange for approving his BPL card without proper documentation.

Responses were recorded on a five-point Likert scale ranging from "strongly disagree" to "strongly agree." Table 2 reports the output from linear regression models of the following form for the responses to each of these seven questions:

$$
y_{i v}=\beta_{0}+\beta_{1} \operatorname{Exp}+\beta_{2} \text { Female }+\beta_{3} \operatorname{Exp} \times \text { Female }+\gamma \mathbf{X}_{i v}+\varepsilon_{i v}
$$

Here $y_{i v}$ is the response to a question from politician $i$ in village council (GP) $v$; Exp denotes a dummy variable that takes the value of 1 if the politician has prior political experience; Female is a dummy variable that takes the value 1 if the politician is female. The outcome variables are dummy variables that take the value 1 if the participant "strongly disagrees" or "disagrees" with the statement of interest. $\mathbf{X}_{i v}$ denotes a vector of individual characteristics of each politician. These include years of education (the reference category is having no more than primary schooling), caste/religion (the reference category is Muslim), land ownership, primary occupation, total number of political leaders in the family, and whether the individual has had prior experience in any leadership position. ${ }^{26}$

In addition to the difference-in-difference estimate $\left(\operatorname{Exp} \times\right.$ Female, $\left.\beta_{3}\right)$, we are also interested in the difference estimates listed at the bottom of the table: Inexp Female - Inexp Male $\left(\beta_{2}\right)$; Exp Female - Exp Male $\left(\beta_{2}+\beta_{3}\right)$; Exp Female - Inexp Female $\left(\beta_{1}+\beta_{3}\right)$; and Exp Male - Inexp Male $\left(\beta_{1}\right)$. These differences capture differences in averages for the various groups, holding the additional controls at their sample means.

The results presented in Table 2 show that experienced politicians, both men and women, express a stronger distaste for corruption than inexperienced politicians. The difference estimates presented in the bottom two rows of the bottom panel of Table 2 are always positive and often statistically significant. If anything, the effects are stronger for men, though the difference-in-difference estimates are never statistically significant. There are no significant differences between the attitudes expressed by women and men, whether inexperienced or experienced. $^{27}$

\footnotetext{
${ }^{26}$ In additional specifications we also include dummies for nominating party (AITC candidate) and whether the politician was elected from a reserved seat. The results are qualitatively and quantitatively similar to those presented in Tables 4. Results for the additional specification are available on request.

${ }^{27}$ In Table A1 in the Appendix we present the results without the additional controls. These are estimates from a restricted version of equation (1), with $\mathbf{X}_{i v}$ excluded from the set of explanatory variables. These are of interest as they capture the actual change in political leadership that took place in these local councils in 2018. These results are qualitatively similar to those presented in Table 2, though the difference estimates are weaker in magnitude.
} 
Table 2: Attitudes towards dishonest behavior

\begin{tabular}{|c|c|c|c|c|c|c|c|}
\hline & (1) & $(2)$ & (3) & (4) & (5) & (6) & $(7)$ \\
\hline Exp & $\begin{array}{c}0.074 \\
(0.056)\end{array}$ & $\begin{array}{l}0.101^{*} \\
(0.060)\end{array}$ & $\begin{array}{c}0.149^{* * *} \\
(0.056)\end{array}$ & $\begin{array}{l}0.096^{*} \\
(0.054)\end{array}$ & $\begin{array}{l}0.090^{*} \\
(0.052)\end{array}$ & $\begin{array}{l}0.088^{*} \\
(0.051)\end{array}$ & $\begin{array}{r}0.112^{* *} \\
(0.050)\end{array}$ \\
\hline Female & $\begin{array}{c}0.060 \\
(0.065)\end{array}$ & $\begin{array}{c}0.007 \\
(0.073)\end{array}$ & $\begin{array}{c}0.019 \\
(0.071)\end{array}$ & $\begin{array}{c}0.026 \\
(0.062)\end{array}$ & $\begin{array}{c}0.063 \\
(0.067)\end{array}$ & $\begin{array}{c}0.019 \\
(0.062)\end{array}$ & $\begin{array}{c}0.004 \\
(0.058)\end{array}$ \\
\hline Exp $\times$ Female & $\begin{array}{l}-0.056 \\
(0.068)\end{array}$ & $\begin{array}{l}-0.036 \\
(0.075)\end{array}$ & $\begin{array}{l}-0.065 \\
(0.071)\end{array}$ & $\begin{array}{l}-0.083 \\
(0.066)\end{array}$ & $\begin{array}{c}-0.002 \\
(0.063)\end{array}$ & $\begin{array}{c}-0.014 \\
(0.061)\end{array}$ & $\begin{array}{l}-0.040 \\
(0.057)\end{array}$ \\
\hline Constant & $\begin{array}{c}0.325^{* *} \\
(0.149)\end{array}$ & $\begin{array}{c}0.384^{* *} \\
(0.156)\end{array}$ & $\begin{array}{c}0.500^{* * *} \\
(0.150)\end{array}$ & $\begin{array}{c}0.504^{* * *} \\
(0.139)\end{array}$ & $\begin{array}{c}0.509^{* * *} \\
(0.145)\end{array}$ & $\begin{array}{c}0.634^{* * *} \\
(0.121)\end{array}$ & $\begin{array}{c}0.643^{* * *} \\
(0.116)\end{array}$ \\
\hline Controls & Yes & Yes & Yes & Yes & Yes & Yes & Yes \\
\hline Sample Size & 356 & 356 & 356 & 356 & 356 & 356 & 356 \\
\hline \multicolumn{8}{|l|}{ Difference Estimate } \\
\hline Inexp F - Inexp M & $\begin{array}{c}0.0600 \\
(0.0650)\end{array}$ & $\begin{array}{l}0.00711 \\
(0.0728)\end{array}$ & $\begin{array}{c}0.0190 \\
(0.0714)\end{array}$ & $\begin{array}{c}0.0257 \\
(0.0620)\end{array}$ & $\begin{array}{c}0.0630 \\
(0.0669)\end{array}$ & $\begin{array}{c}0.0193 \\
(0.0619)\end{array}$ & $\begin{array}{l}0.00372 \\
(0.0584)\end{array}$ \\
\hline $\operatorname{Exp} F-\operatorname{Exp} M$ & $\begin{array}{l}0.00431 \\
(0.0647)\end{array}$ & $\begin{array}{l}-0.0287 \\
(0.0741)\end{array}$ & $\begin{array}{l}-0.0459 \\
(0.0664)\end{array}$ & $\begin{array}{l}-0.0574 \\
(0.0596)\end{array}$ & $\begin{array}{c}0.0611 \\
(0.0637)\end{array}$ & $\begin{array}{l}0.00506 \\
(0.0575)\end{array}$ & $\begin{array}{l}-0.0365 \\
(0.0519)\end{array}$ \\
\hline Exp F - Inexp F & $\begin{array}{c}0.0186 \\
(0.0430)\end{array}$ & $\begin{array}{c}0.0656 \\
(0.0493)\end{array}$ & $\begin{array}{l}0.0844^{*} \\
(0.0502)\end{array}$ & $\begin{array}{c}0.0132 \\
(0.0439)\end{array}$ & $\begin{array}{l}0.0877^{*} \\
(0.0471)\end{array}$ & $\begin{array}{l}0.0735^{*} \\
(0.0412)\end{array}$ & $\begin{array}{l}0.0720^{* *} \\
(0.0355)\end{array}$ \\
\hline Exp M - Inexp M & $\begin{array}{c}0.0743 \\
(0.0562)\end{array}$ & $\begin{array}{c}0.101^{*} \\
(0.0599)\end{array}$ & $\begin{array}{c}0.149^{* * *} \\
(0.0561)\end{array}$ & $\begin{array}{l}0.0962^{*} \\
(0.0544)\end{array}$ & $\begin{array}{l}0.0895^{*} \\
(0.0517)\end{array}$ & $\begin{array}{l}0.0877^{*} \\
(0.0512)\end{array}$ & $\begin{array}{l}0.112^{* *} \\
(0.0505)\end{array}$ \\
\hline
\end{tabular}

Notes: Standard errors clustered at the GP level. Significance: ${ }^{* * *} p<0.01 ;^{* *} p<0.05 ;^{*} p<0.1$. Regressions control for a set of individual characteristics (age, years of schooling, religion/caste, land owned, political network and primary occupation). Full set of results presented in Table B1. Outcomes are 1 if the respondents strongly disagree with each statement.

\subsection{Trust in institutions elicited via surveys}

Attitudes towards corruption may be shaped by (and shape) the trust politicians express towards political institutions and other politicians. To explore trust in local political institutions, and in the local representatives in the state legislative assembly (MLA) and parliament (MP), we asked the following questions:

1. How much of the time do you think you can trust the gram panchayat here to do what is right?

2. How much of the time do you think you can trust the gram pradhan here to do what is right?

3. How much of the time do you think you can trust the local MLA here to do what is right?

4. How much of the time do you think you can trust the local MP here to do what is right?

Here, too, responses were recorded on a Likert scale, this time a four-point scale ranging from "just about always" to "almost never." Respondents were also given a "do not know" option. Again, we estimate the type of regressions in equation (1), where the dependent 
variables take on the value 1 if the participant responds by saying "just about always" or "most of the time."

While the difference estimates presented in the bottom panel of Table 3 suggest that, among inexperienced politicians, there is no gender difference in trust in politicians, more experienced politicians - both men and women - can be seen to be less trusting of politicians at every level. While the effects are not statistically significant in most cases (the exception being trust in the local MLA for women), all results point in the same direction. ${ }^{28}$

Table 3: Trust in political institutions doing what is right

\begin{tabular}{|c|c|c|c|c|}
\hline & $\begin{array}{l}\text { GP } \\
(1) \\
\end{array}$ & $\begin{array}{c}\text { Gram Pradhan } \\
(2)\end{array}$ & $\begin{array}{c}\text { Local MLA } \\
\text { (3) }\end{array}$ & $\begin{array}{c}\text { Local MP } \\
(4)\end{array}$ \\
\hline Exp & $\begin{array}{l}-0.032 \\
(0.045)\end{array}$ & $\begin{array}{l}-0.041 \\
(0.048)\end{array}$ & $\begin{array}{l}-0.045 \\
(0.084)\end{array}$ & $\begin{array}{l}-0.082 \\
(0.093)\end{array}$ \\
\hline Female & $\begin{array}{l}-0.016 \\
(0.050)\end{array}$ & $\begin{array}{c}0.037 \\
(0.043)\end{array}$ & $\begin{array}{l}-0.040 \\
(0.087)\end{array}$ & $\begin{array}{c}0.053 \\
(0.098)\end{array}$ \\
\hline Exp $\times$ Female & $\begin{array}{c}0.008 \\
(0.052)\end{array}$ & $\begin{array}{c}0.037 \\
(0.054)\end{array}$ & $\begin{array}{l}-0.107 \\
(0.103)\end{array}$ & $\begin{array}{l}-0.048 \\
(0.110)\end{array}$ \\
\hline Constant & $\begin{array}{c}0.948^{* * *} \\
(0.101)\end{array}$ & $\begin{array}{c}0.936^{* * *} \\
(0.093)\end{array}$ & $\begin{array}{c}0.808^{* * *} \\
(0.186)\end{array}$ & $\begin{array}{c}0.426 * * \\
(0.200)\end{array}$ \\
\hline $\begin{array}{l}\text { Controls } \\
\text { Sample Size }\end{array}$ & $\begin{array}{l}\text { Yes } \\
356\end{array}$ & $\begin{array}{l}\text { Yes } \\
356\end{array}$ & $\begin{array}{l}\text { Yes } \\
356\end{array}$ & $\begin{array}{l}\text { Yes } \\
356\end{array}$ \\
\hline \multicolumn{5}{|l|}{ Difference Estimate } \\
\hline Inexp Female - Inexp Male & $\begin{array}{l}-0.0159 \\
(0.0505)\end{array}$ & $\begin{array}{c}0.0369 \\
(0.0430)\end{array}$ & $\begin{array}{l}-0.0404 \\
(0.0872)\end{array}$ & $\begin{array}{c}0.0531 \\
(0.0983)\end{array}$ \\
\hline Exp Female - Exp Male & $\begin{array}{r}-0.00796 \\
(0.0603)\end{array}$ & $\begin{array}{c}0.0743 \\
(0.0515)\end{array}$ & $\begin{array}{l}-0.147 \\
(0.102)\end{array}$ & $\begin{array}{c}0.00480 \\
(0.107)\end{array}$ \\
\hline Exp Female - Inexp Female & $\begin{array}{l}-0.0239 \\
(0.0409)\end{array}$ & $\begin{array}{l}-0.00402 \\
(0.0386)\end{array}$ & $\begin{array}{l}-0.152^{* *} \\
(0.0794)\end{array}$ & $\begin{array}{c}-0.131 \\
(0.0852)\end{array}$ \\
\hline Exp Male - Inexp Male & $\begin{array}{l}-0.0319 \\
(0.0453)\end{array}$ & $\begin{array}{l}-0.0414 \\
(0.0478)\end{array}$ & $\begin{array}{l}-0.0449 \\
(0.0840)\end{array}$ & $\begin{array}{l}-0.0825 \\
(0.0927)\end{array}$ \\
\hline
\end{tabular}

Notes: Standard errors clustered at the GP level. Significance: ${ }^{* * *} p<0.01 ;^{* *} p<$ $0.05 ;^{*} p<0.1$. Dependent variable $=1$ if responder reports trusting the relevant political institution just about always or most of the time. Regressions control for age, years of schooling, religion/caste, land owned, political network and primary occupation. Full set of results presented in Table B2.

\subsection{Results from experimental tasks}

Incentivized experimental tasks allow us to avoid the self-reporting and social-desirability biases survey responses are vulnerable to. Our respondents took part in a series of decision-making tasks, consisting of: (1) a dictator game, studying generosity/altruism (Forsythe et al., 1994);

\footnotetext{
${ }^{28}$ These findings are consistent with those presented in Table A2, where we do not include controls.
} 
(2) an ultimatum game, studying respondents' notions of fairness (Güth et al., 1982); (3) a trust game, studying the inclination to trust a stranger and behave in a trustworthy manner (Berg et al., 1995); (4) a public goods game with a punishment option, studying cooperation and norm enforcement (Ledyard, 1995, Chaudhuri, 2011); (5) an investment-decision game, studying attitudes to risk (Gneezy and Potters, 1997); and finally (6) a die-tossing game, designed as a test for honesty (Fischbacher and Föllmi-Heusi, 2013). ${ }^{29}$

In each of the paired games, subjects played both the role of first- and second-mover. Multiple research assistants concurrently collected data and were trained to not deviate from the experimental protocol. All interactions were carried out on a one-on-one basis between enumerator and participant, with each session lasting around ninety minutes. Once the day's data collection had been completed, respondents for the paired games were randomly matched. Importantly, a respondent was never matched with another respondent from the same panchayat. For each of the paired games, only one of either the first- or second-mover decision was used to determine monetary payoffs, which were paid to the respondents in rupees within a specified time period, typically the next day. On average, participants earned Rs.800 (US\$ 80 using PPP exchange rate) from the experimental games. This represents a substantial amount for local politicians, the majority of whom receive a monthly government stipend of Rs.1000 a month.

\subsection{Gender differences in dishonesty}

We capture dishonest behavior through a die-tossing task, with participants asked to throw an unbiased die thirty times in private and then report the number of sixes rolled. Participants were told they would be paid Rs.5 for each reported six. It was made clear that the die tossings would not be monitored, and every effort was made to guarantee participant privacy. ${ }^{30}$

While it is impossible to know for certain whether a particular individual has cheated, knowledge of the statistical distribution of responses allows us to infer how the reported number of sixes differ from a theoretical distribution, as well as across the four sub-groups of interest. As participants were throwing an unbiased die, over thirty rolls an average of five sixes should be expected. In our data, the average number of reported sixes is eight (ranging from one to twenty-seven), indicating that even in this test setting - where some social-desirability bias would be expected - many participants engaged in dishonest behavior for personal gain.

Figure 3 presents the distribution of reported sixes by male and female, experienced and inexperienced politicians. The distributions indicate that experienced female politicians are likely to report more sixes than the other three groups. The average number of reported

\footnotetext{
${ }^{29}$ The results from the ultimatum game and the public goods game with punishment option are analyzed in a separate paper, see Chauduri et al 2020.

${ }^{30}$ Versions of this task are increasingly used to investigate dishonest behavior in developing countries. See for example Hanna and Wang (2016), Kosfeld and Rustagi (2015).
} 
Figure 3: Distribution of reported sixes in die-tossing game

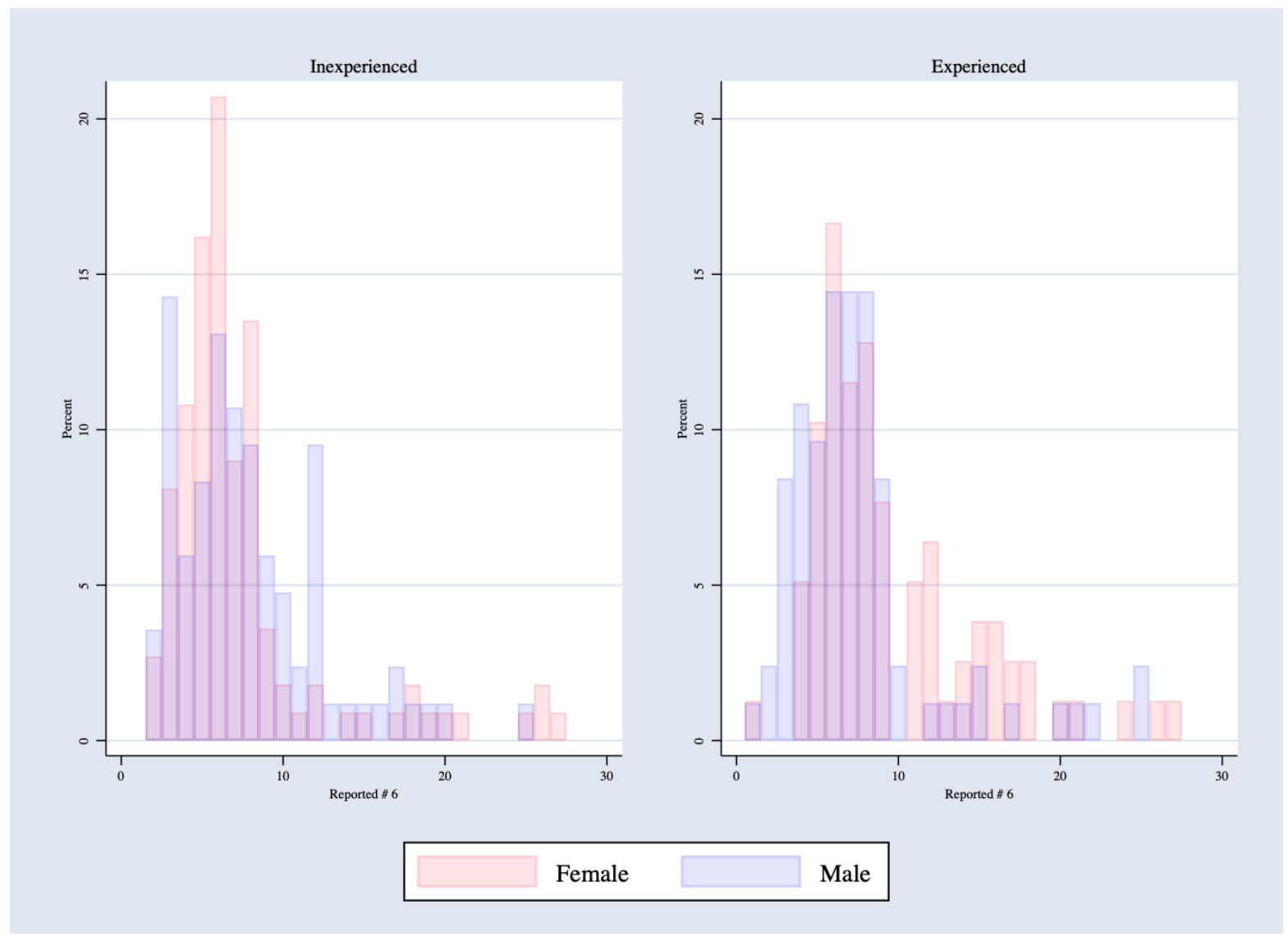

sixes is $7.9,7.5,7.7$ and 9.7 for, respectively, male inexperienced, female inexperienced, male experienced and female experienced. A similar pattern is observed when we estimate multivariate linear models on these data (regression specification given by equation 1), as reported in column 1 of Table 4 . The difference-in-difference estimate $(\operatorname{Exp} \times$ Female) is positive and statistically significant.

At the bottom of Table 4, we show pair-wise comparisons of our four groups of interest. Consistent with the expectation that women are less prone to dishonesty when entering political office, our estimate is that they report 1.1 fewer sixes than men (see column 1). This difference is substantial, though not statistically significant. In contrast, experienced female politicians report an estimated 1 more six compared to experienced male politicians, though this difference is also statistically insignificant. In total, this means experienced female politicians report 2.6 more sixes compared to inexperienced female politicians, even when controlling for a host of different personal characteristics, and this difference - which is consistent with a substantial time-in-office effect - is statistically significant ( $\mathrm{p}$-value $<0.05$ ). There is no similar difference between inexperienced and experienced men, suggesting that the behavioral response and learning trajectories of men and women in office differ. 
Table 4: Behavior in experimental tasks

\begin{tabular}{lccccc}
\hline & $\begin{array}{c}\text { Reported } \\
\# \text { sixes } \\
(1)\end{array}$ & $\begin{array}{c}\text { Dictator } \\
\text { offer } \\
(2)\end{array}$ & $\begin{array}{c}\text { Trust Offer } \\
\text { offer } \\
(3)\end{array}$ & $\begin{array}{c}\text { Trust } \\
\text { response } \\
(4)\end{array}$ & $\begin{array}{c}\text { Risk } \\
\text { preference } \\
(5)\end{array}$ \\
\hline Exp & 0.526 & 1.473 & -1.196 & 0.021 & -1.453 \\
Female & $(0.926)$ & $(4.092)$ & $(4.802)$ & $(0.029)$ & $(5.362)$ \\
& -1.085 & -0.342 & -3.189 & 0.016 & $-7.398^{*}$ \\
Exp $\times$ Female & $(0.998)$ & $(4.530)$ & $(5.651)$ & $(0.031)$ & $(4.142)$ \\
& $2.114^{*}$ & -1.024 & 4.203 & -0.009 & $9.748^{*}$ \\
Constant & $(1.125)$ & $(5.299)$ & $(5.650)$ & $(0.035)$ & $(5.578)$ \\
& $11.343^{* * *}$ & $64.174^{* * *}$ & $74.235^{* * *}$ & $0.263^{* * *}$ & $79.897^{* * *}$ \\
& $(2.343)$ & $(7.019)$ & $(9.234)$ & $(0.069)$ & $(10.113)$ \\
\hline Controls & Yes & Yes & Yes & Yes & Yes \\
Sample Size & 356 & 356 & 356 & 356 & 356 \\
\hline Difference Estimates & & & & & \\
Inexp Female - Inexp Male & -1.085 & -0.342 & -3.189 & 0.0159 & $-7.398^{*}$ \\
& $(0.998)$ & $(4.530)$ & $(5.651)$ & $(0.0313)$ & $(4.142)$ \\
Exp Female - Exp Male & 1.029 & -1.366 & 1.015 & 0.00697 & 2.349 \\
& $(1.098)$ & $(5.828)$ & $(5.175)$ & $(0.0368)$ & $(6.288)$ \\
Exp Female - Inexp Female & $2.641^{* *}$ & 0.449 & 3.007 & 0.0122 & $8.295^{*}$ \\
& $(0.970)$ & $(4.264)$ & $(3.621)$ & $(0.0309)$ & $(4.932)$ \\
Exp Male - Inexp Male & 0.526 & 1.473 & -1.196 & 0.0212 & -1.453 \\
& $(0.926)$ & $(4.092)$ & $(4.802)$ & $(0.0285)$ & $(5.362)$ \\
\hline
\end{tabular}

Notes: Standard errors clustered at the GP level. Significance: ${ }^{* * *} p<0.01 ;^{* *} p<0.05 ;^{*} p<$ 0.1. Regressions control for a set of individual characteristics (age, years of schooling, religion/caste, land owned, political network and primary occupation). Full set of results presented in Table B3.

\subsection{Probing the mechanisms for change}

In the earlier theoretical discussion, we proposed pro-sociality, risk aversion and aspirations as possible mechanisms that could explain gender differences in dishonesty and how this gap evolves over time in office. In the previous section, we found that women appear to change more during their time in office than men, becoming more likely to cheat for private gain. Can this difference be attributed to any of the proposed mechanisms?

\section{The pro-social mechanism}

To explore the pro-social mechanism, we use two well-known behavioral games: the dictator game and the trust game. The dictator game is a two-person game with an allocator and a recipient. Each allocator is given an endowment of $E$ (Rs.100). The allocator must then decide whether to share this - and, if so, how much-with an anonymous recipient, $x \in\{0,10,20, \ldots, 100\}$. The recipient has no decision to make and does not have an initial endowment. Hence, given an allocation $x$, the allocator's income is $(100 x)$ and the recipient's income is $x$. Dictator games have been extensively used by social scientists to measure generosity or altruism on the part of the allocator. 
The trust game is, again, a two-person, with one player designated the sender and the other the responder. The sender is given an initial endowment of $E$ (Rs.100), and asked to decide whether to transfer any part of this endowment, $x \in\{0,10,20, \ldots, 100\}$, to an anonymous responder. The experimenter triples the value of $\mathrm{x}$ and gives the amount to the matched responder, who is then asked to decide whether to return any money to the sender, and if so how much. The sender's earning is $(100-x+R)$, with $R$ being the amount returned by the responder; while the responder's earning is $(3 x-R)$. We used the strategy method to give the responder a menu of options conditional on the amount received. As any positive amount transferred is tripled, the responder states how much they will return for each value of $3 x$.

Backward induction suggests a purely money-maximizing responder has no incentive to send money back. Anticipating this, the sender should not transfer any money in the first instance, implying that both players will end the game with their initial endowments. However, if players are motivated by trust and reciprocity, both can be monetarily better off.

For completeness, we present the results for both the first-mover and second-mover decisions in the trust game. The first-mover decision ("trust offer") is typically used as a measure of trust, while the second-mover decision is a measure of the second-mover's trustworthiness ("trust response"). With regard to dishonesty, the second-mover decision is most relevant. Existing evidence suggests that by sending money back to the first-mover, second-movers are typically influenced both by altruism (and hence the need to control behavior in the dictator game) and reciprocity (Cox, 2004, Ashraf et al., 2006, Chaudhuri and Gangadharan, 2007). Our argument is that taken together, the three decisions - altruism (as measured by the dictator game), trust (as measured by the first-mover decision in the trust game) and trustworthiness (as measured by the second-mover decision in the trust game)-provide a metric of a person's degree of pro-sociality, which may in turn have a bearing on honesty/dishonesty.

Regression results for these two games are presented in columns 2-4 of Table 4. Again, the regression specification is given by equation (1). In column 2 , the outcome variable is the offer made in the dictator game. At the bottom of the table we show pair-wise comparisons for each of our four groups. While the difference estimates are not statistically significant, they do point in the direction of male politicians being more altruistic than female politicians, and of time in office making politicians - whether male or female - somewhat more altruistic. In other words, we find no evidence of the female politicians in our sample being more pro-social.

In columns 3 and 4 in Table 4 we present the results of the trust game. While none of the differences are statistically significant, the coefficients suggest that experienced men are less trusting, and experienced women more trusting, than their inexperienced counterparts. Though inexperienced males start off more trusting than their female counterparts, the patterns switch with experience. The coefficients for the second part of the game-measuring the trustworthiness of politician participants - are all small and statistically insignificant. These 
results, therefore, provide little evidence of politicians becoming less pro-social and more selfish during their time in office.

\section{The risk aversion mechanism}

The second explanation relates to gender differences in preferences for risk, which we call the risk aversion mechanism. Risk preferences are elicited using the investment game, as proposed and discussed in Gneezy and Potters (1997). In this game, each player is given the option of investing any part of an initial endowment of Rs.100 in a hypothetical risky project. The project offers a 50 per cent probability of tripling the amount invested, and a 50 per cent probability of losing it. The individual can keep any amount they choose not to invest. The higher the investment in the risky asset, the less risk averse a person is interpreted to be.

We present the results from the investment game in Column 5 of Table 4 . The difference estimates show that inexperienced female politicians invest about 7.4 percentage points (or 11 per cent given the mean allocation of inexperienced male politicians) less than inexperienced males, which is statistically significant. This suggests that inexperienced female politicians are considerably more risk averse than inexperienced male politicians. However, this difference disappears over time: experienced female politicians invest 8.4 percentage points (or 15 per cent) more than inexperienced female politicians. There is little difference in investment evident between inexperienced and experienced male politicians, indicating that this behavioral change is confined to female politicians, who enter office more risk averse than men, but become less risk averse over the course of their time in office.

Our findings suggest that the notable difference in dishonesty between inexperienced and experienced women in the die-tossing game could be due to differences in their level of risk aversion. This is further corroborated by the fact that behavior in the investment game and in the die-tossing game are positively correlated, as illustrated in Figure 4. This correlation is particularly strong for experienced female politicians.

\section{The aspiration mechanism}

A third possible mechanism for the changing gender gap in dishonesty is differences in aspirations about a future role in politics between male and female politicians. If women have lower political aspirations, they may be more attracted to short-term gains from office. To examine the validity of this mechanism, we asked survey participants whether they aspired to stand for office in the future. Figure 5 presents the average proportion responding "yes" to aspiring to stand for any of the following positions: same as current, pradhan, member of panchayat samiti, member of zila parishad, MLA, MP. There is no evidence of a gender difference in reported aspiration for future political office, either for experienced or inexperienced

politicians, though both men and women in the latter category report a significantly higher 
Figure 4: Correlation between amount invested in risky asset and reported number of sixes in dishonesty task



willingness to stand for political office than their experienced counterparts. These results are corroborated using multivariate regressions (see Table A4). This suggests that the aspirations channel cannot explain the gender difference in dishonesty.

\section{Concluding discussion}

Increasing the share of women in politics has been promoted as a way of reducing corruption and curtailing dishonest behavior. However, relatively little is known about why and under what circumstances women are more honest and less corrupt than men. Among ordinary citizens, women have been found to be more altruistic and honest, at least in industrialized countries. It requires, though, a considerable leap of faith to argue a similar behavioral pattern should be expected among elected women politicians across the world, as does the assumption that gender gaps in attitudes and behavior will remain static as newly elected representatives become socialized into heterogeneous and localized political cultures.

This paper contributes to the debate on the gender gap in dishonesty, with our findings 
Figure 5: Aspiration for political office in the future

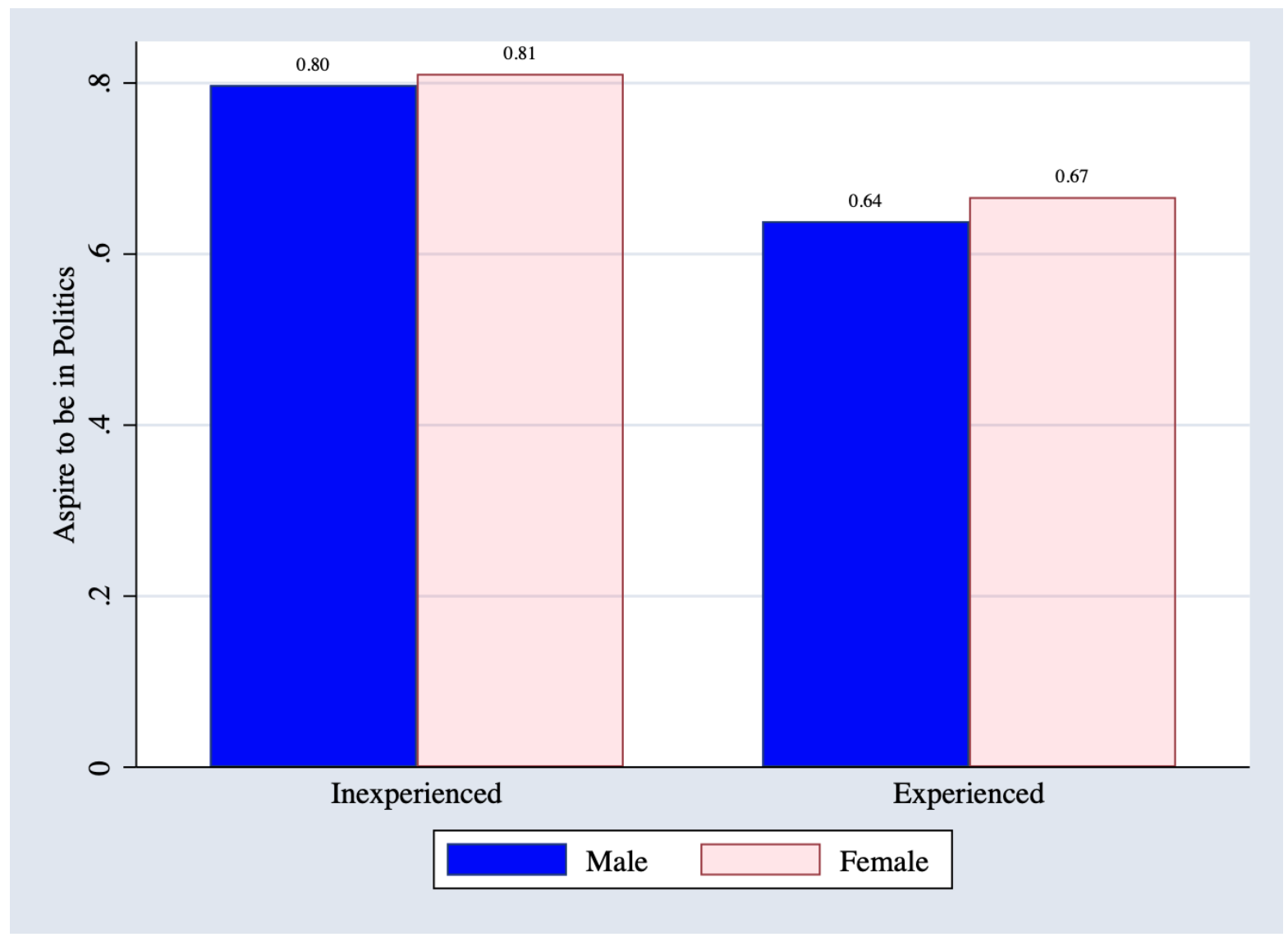

underlining the importance of not assuming that changes in expressed attitudes are echoed in behavior. Indeed, when asked, experienced politicians express greater distaste for corruption than their less experienced colleagues, while simultaneously-particularly women - cheating more for personal gain in behavioral games. Though inexperienced women were somewhat less dishonest than their male colleagues when entering office, we find experienced women to be significantly more dishonest. Our findings suggest this may be due to a time-in-office effect of female politicians becoming less risk averse.

Our study indicates that gender gaps in the attitudes and behaviors of politicians gap should be treated as dynamic rather than static, meaning it is important to take into account politicians' levels of experience. More research is needed to establish conclusively whether what we are picking up is evidence of a shrinking gender gap as men and women are socialized into the same political environment, or whether exposure to the political game makes women more dishonest than the men they work with. Whichever of these patterns better describe reality, our study of real-life politicians lends little support to the idea that women's entry into political institutions will help clean out corruption or other malfeasance-except, perhaps, for a short period of time. 


\section{References}

Afridi, F., Iversen, V., and Sharan, M. (2017). Women political leaders, corruption and learning: Evidence from a large public program in India. Economic Development and Cultural Change, 66(1):1-30.

Alatas, V., Cameron, L., Chaudhuri, A., Erkal, N., and Gangadharan, L. (2009). Gender, culture, and corruption: Insights from an experimental analysis. Southern Economic Journal, pages $663-680$.

Ashraf, N., Bohnet, I., and Piankov, N. (2006). Decomposing trust and trustworthiness. Experimental Economics, 9(3):193-208.

Ban, R. and Rao, V. (2008). Tokenism or agency? The impact of women's reservations on village democracies in South India. Economic Development and Cultural Change, 56(3):501530 .

Barnes, T. D. and Beaulieu, E. (2019). Women politicians, institutions, and perceptions of corruption. Comparative Political Studies, 52(1):134-167.

Baskaran, T., Bhalotra, S. R., Min, B. K., and Uppal, Y. (2018). Women legislators and economic performance. WIDER Working Paper 47/2018.

Basu, A. (2016). Women, dynasties and democracy in India. In Chandra, K., editor, Democratic Dynasties: State, Party and Political Families in India. Cambridge University Press.

Beaman, L., Chattopadhyay, R., Duflo, E., Pande, R., and Topalova, P. (2009). Powerful Women: Does Exposure Reduce Prejudice? Quarterly Journal of Economics, 124(4):14971540 .

Berg, J., Dickhaut, J., and McCabe, K. (1995). Trust, reciprocity, and social history. Games and Economic Behavior, 10(1):122-142.

Besley, T., Folke, O., Persson, T., and Rickne, J. (2017). Gender quotas and the crisis of the mediocre man: Theory and evidence from Sweden. American Economic Review, 107(8):2204-42.

Bhattacharya, D. (2012). Panchayati Raj in West Bengal: A synthesis of existing research. Technical report.

Bhattacharya, M. (2002). Panchayati Raj in West Bengal: Democratic Decentralisation Or Democratic Centralism. Manak Publications.

Bhavnani, R. (2012). Using asset disclosures to study politicians' rents: An application to India. Working paper.

Bjarnegård, E. (2013). Gender, informal institutions and political recruitment: Explaining male dominance in parliamentary representation. Springer.

Borooah, V. K. (2016). Deconstructing corruption: A study of cash for favours in rural India. Journal of South Asian Development, 11(1):1-37.

Brollo, F. and Troiano, U. (2016). What happens when a woman wins an election? Evidence from close races in Brazil. Journal of Development Economics, 122:28-45.

Campbell, R., Childs, S., and Lovenduski, J. (2010). Do women need women representatives? British Journal of Political Science, 40(1):171-194.

Chandra, K. (2016). Democratic Dynasties State, Party, and Family in Contemporary Indian Politics. Cambridge University Press, Cambridge. 
Chattopadhyay, R. and Duflo, E. (2004a). Impact of Reservation in Panchayati Raj: Evidence from a nationwide randomised experiment. Economic and Political Weekly, 39:979-986.

Chattopadhyay, R. and Duflo, E. (2004b). Women as policy makers: Evidence from a randomized policy experiment in India. Econometrica, 72(5):1409-1443.

Chaudhuri, A. (2011). Sustaining cooperation in laboratory public goods experiments: a selective survey of the literature. Experimental Economics, 14(1):47 - 83.

Chaudhuri, A. (2012). Gender and corruption: A survey of the experimental evidence. In Serra, D. and Wantchekon, L., editors, New Advances in Experimental Research on Corruption, chapter 2, pages 13-49. Emerald Group Publishing Limited.

Chaudhuri, A. and Gangadharan, L. (2007). An experimental analysis of trust and trustworthiness. Southern Economic Journal, 73(4):959 - 985.

Clots-Figueras, I. (2005). Women in Politics. Evidence from the Indian states. Available at SSRN: http://ssrn.com/abstract $=894111$.

Cox, J. C. (2004). How to identify trust and reciprocity. Games and Economic Behavior, $46(2): 260-281$.

Croson, R. and Gneezy, U. (2009). Gender differences in preferences. Journal of Economic literature, $47(2): 448-74$.

Dahlerup, D. (2006). Women, quotas and politics. Routledge, London ; New York.

Dahlerup, D., Hilal, Z., Kalandadze, N., and Kandawasvika-Nhundu, R. (2014). Atlas of electoral gender quotas. IDEA.

D'Attoma, J., Volintiru, C., and Steinmo, S. (2017). Willing to share? Tax compliance and gender in Europe and America. Research \& Politics, 4(2):1-10.

Debski, J., Jetter, M., Mösle, S., and Stadelmann, D. (2018). Gender and corruption: The neglected role of culture. European Journal of Political Economy, https://doi.org/10.1016/j.ejpoleco.2018.05.002.

Dollar, D., Fisman, R., and Gatti, R. (2001). Are women really the "fairer" sex? Corruption and women in government. Journal of Economic Behavior 83 Organization, 46(4):423-429.

Dreber, A. and Johannesson, M. (2008). Gender differences in deception. Economics Letters, 99(1):197-199.

Duflo, E. and Topalova, P. (2004). Unappreciated service: Performance, perceptions, and women leaders in India. Working paper. Department of Economics, MIT.

Eckel, C. and Grossman, P. (1998). Are women less selfish than men? Evidence from dictator experiments. Economic Journal, 108(448):726 - 735.

Eckel, C. C. and Grossman, P. J. (2002). Sex differences and statistical stereotyping in attitudes toward financial risk. Evolution and human behavior, 23(4):281-295.

Enemark, D., Gibson, C. C., McCubbins, M. D., and Seim, B. (2016). Effect of holding office on the behavior of politicians. Proceedings of the National Academy of Sciences, 113(48):1369013695 .

Esarey, J. and Schwindt-Bayer, L. A. (2018). Women's representation, accountability and corruption in democracies. British Journal of Political Science, 48(3):659-690. 
Ferraz, C. and Finan, F. (2011). Electoral accountability and corruption: Evidence from the audits of local governments. American Economic Review, 101(4):1274 - 1311.

Fischbacher, U. and Föllmi-Heusi, F. (2013). Lies in disguise - an experimental study on cheating. Journal of the European Economic Association, 11(3):525-547.

Fisman, R., Schulz, F., and Vig, V. (2014). The private returns to public office. Journal of Political Economy, 122(4):806-862.

Fletschner, D., Anderson, C. L., and Cullen, A. (2010). Are women as likely to take risks and compete? Behavioural findings from Central Vietnam. The Journal of Development Studies, 46(8):1459-1479.

Forsythe, R., Horowitz, J. L., Savin, N. E., and Sefton, M. (1994). Fairness in simple bargaining experiments. Games and Economic Behavior, 6(3):347 - 369.

Friesen, L. and Gangadharan, L. (2012). Individual level evidence of dishonesty and the gender effect. Economics Letters, 117(3):624-626.

Ghatak, M. and Ghatak, M. (2002). Recent reforms in the Panchayat System in West Bengal: Toward greater participatory governance? Economic and Political Weekly, 37(1):5 - 11.

Gneezy, U. and Potters, J. (1997). An experiment on risk taking and evaluation periods. Quarterly Journal of Economics, 11292:631-645.

Goetz, A. M. (2007). Political cleaners: Women as the new anti-corruption force? Development and Change, 38(1):87-105.

Grimes, M. and Wängnerud, L. (2010). Curbing corruption through social welfare reform? The effects of Mexico's conditional cash transfer program on good government. The American Review of Public Administration, 40(6):671-690.

Güth, W., Schmittberger, R., and Schwarze, B. (1982). An experimental analysis of ultimatum bargaining. Journal of Economic Behavior ES Organization, 3(4):367 - 388.

Hanna, R. and Wang, S. (2016). Dishonesty and selection into public service: Evidence from india. Technical report, Harvard University, University of Pennsylvania and BREAD.

Heath, M. R., Schwindt-Bayer, L. A., and Taylor-Robinson, M. M. (2005). Women on the sidelines: Women's representation on committees in Latin American legislatures. American Journal of Political Science, 49(2):420-436.

Jensenius, F. R. (2019). India: A contradictory record. In The Palgrave Handbook of Women's Political Rights, pages 673-688. Springer.

Jha, C. K. and Sarangi, S. (2018). Women and corruption: What positions must they hold to make a difference? Journal of Economic Behavior 83 Organization, 151(C):219-233.

Jianakoplos, N. A. and Bernasek, A. (1998). Are women more risk averse? Economic inquiry, $36(4): 620-630$.

Kanango, S. D. (1998). People's Power and Panchayati Raj: Theory and Practice, chapter Panchayati Raj and Emerging Women Leadership: An Overview, pages 77 - 95. Kolkata: Indian Social Institute.

King, D. C. and Matland, R. E. (2003). Sex and the grand old party: An experimental investigation of the effect of candidate sex on support for a republican candidate. American Politics Research, 31(6):595-612. 
Kosfeld, M. and Rustagi, D. (2015). Leader punishment and cooperation in groups: Experimental field evidence from commons management in Ethiopia. American Economic Review, 105(2):747-783.

Kröll, M. and Rustagi, D. (2016). Shades of dishonesty and cheating in informal milk markets in India. Technical report, SAFE Working Paper, No. 134, Goethe University Frankfurt.

Krook, M. L. (2006). Reforming representation: The diffusion of candidate gender quotas worldwide. Politics and Gender, 2(03):303-327.

Lambsdorff, F. and Boehm, F. (2011). Gender and corruption: Lessons from laboratory corruption experiments. European Journal of Development Research, 23(1):59 - 71.

Ledyard, J. O. (1995). The Handbook of Experimental Economics., chapter Public Goods: A Survey of Experimental Research, pages 111 - 194. Princeton University Press, Princeton.

Levin, I. P., Snyder, M. A., and Chapman, D. P. (1988). The interaction of experiential and situational factors and gender in a simulated risky decision-making task. The Journal of Psychology, 122(2):173-181.

Lovenduski, J. (1986). Women and European politics: contemporary feminism and public policy. University of Massachusetts Press, Amherst.

Lovenduski, J. and Norris, P. (1993). Gender and party politics. Sage Publications, London.

Naurin, E. and Öhberg, P. (2019). Ethics in elite experiments: A perspective of officials and voters. British Journal of Political Science, pages 1-9.

O'Brien, D. Z. (2015). Rising to the top: Gender, political performance, and party leadership in parliamentary democracies. American Journal of Political Science, 59(4):1022-1039.

Phillips, A. (1995). The Politics of Presence: Democracy and Group Representation. Oxford University Press, New York.

Raabe, K., Sekher, M., and Birner, R. (2009). The effects of political reservations for women on local governance and rural service provision. Working paper.

Rau, H. (2012). Trust and trustworthiness: A survey of gender differences. In McGeowen, S., editor, Psychology of Gender Differences. New York: Nova Science Publishers.

Rehavi, M. M. (2007). Sex and politics: Do female legislators affect state spending. Unpublished manuscript, available online.

Rosenbaum, S. M., Billinger, S., and Stieglitz, N. (2014). Let's be honest: A review of experimental evidence of honesty and truth-telling. Journal of Economic Psychology, 45:181-196.

Roszkowski, M. J. and Grable, J. (2005). Gender stereotypes in advisors' clinical judgments of financial risk tolerance: Objects in the mirror are closer than they appear. The Journal of Behavioral Finance, 6(4):181-191.

Schneider, M. C. and Bos, A. L. (2014). Measuring stereotypes of female politicians. Political Psychology, 35(2):245-266.

Schulze, G. G. and Frank, B. (2003). Deterrence versus intrinsic motivation: Experimental evidence on the determinants of corruptibility. Economics of governance, 4(2):143-160.

Skjeie, H. (1991). The rhetoric of difference: On women's inclusion into political elites. Politics and Society, 19(2):233-263. 
Sung, H.-E. (2003). Fairer sex or fairer system? Gender and corruption revisited. Social Forces, $82(2): 703-723$.

Svaleryd, H. (2009). Women's representation and public spending. European Journal of Political Economy, 25(2):186-198.

Swamy, A., Knack, S., Lee, Y., and Azfar, O. (2001). Gender and corruption. Journal of Development Economics, 64(1):25-55.

Truex, R. (2011). Corruption, attitudes, and education: Survey evidence from Nepal. World Development, 39(7):1133 - 1142 .

Vaishnav, M. (2017). When Crime Pays: Money and Muscle in Indian Politics. Yale University Press, New Haven.

Vijayalakshmi, V. (2008). Rent-seeking and gender in local governance. The Journal of Development Studies, 44(9):1262-1288.

Wangnerud, L. (2009). Women in Parliaments: Descriptive and Substantive Representation. Annual Review of Political Science, 12:51-69.

Wasserman, M. (2020). Gender differences in politician persistence. Technical report, Mimeo. UCLA Anderson School of Management.

WB (2002). Integrating gender into the World Bank's work: a strategy for action. World Bank Report. 


\section{Online Appendix}

\section{Table A1: Attitudes towards dishonest behavior. No additional controls included}

\begin{tabular}{|c|c|c|c|c|c|c|c|}
\hline & (1) & $(2)$ & $(3)$ & $(4)$ & (5) & (6) & $(7)$ \\
\hline Exp & $\begin{array}{c}0.023 \\
(0.050)\end{array}$ & $\begin{array}{c}0.046 \\
(0.056)\end{array}$ & $\begin{array}{c}0.106^{* *} \\
(0.051)\end{array}$ & $\begin{array}{c}0.047 \\
(0.048)\end{array}$ & $\begin{array}{c}0.035 \\
(0.049)\end{array}$ & $\begin{array}{c}0.047 \\
(0.043)\end{array}$ & $\begin{array}{l}0.071^{*} \\
(0.043)\end{array}$ \\
\hline Female & $\begin{array}{c}0.050 \\
(0.045)\end{array}$ & $\begin{array}{c}0.043 \\
(0.053)\end{array}$ & $\begin{array}{c}0.016 \\
(0.055)\end{array}$ & $\begin{array}{c}0.050 \\
(0.045)\end{array}$ & $\begin{array}{c}0.014 \\
(0.048)\end{array}$ & $\begin{array}{c}0.008 \\
(0.044)\end{array}$ & $\begin{array}{c}0.038 \\
(0.044)\end{array}$ \\
\hline Exp $\times$ Female & $\begin{array}{l}-0.057 \\
(0.067)\end{array}$ & $\begin{array}{l}-0.039 \\
(0.075)\end{array}$ & $\begin{array}{l}-0.060 \\
(0.072)\end{array}$ & $\begin{array}{l}-0.094 \\
(0.067)\end{array}$ & $\begin{array}{c}0.006 \\
(0.066)\end{array}$ & $\begin{array}{l}-0.012 \\
(0.059)\end{array}$ & $\begin{array}{l}-0.041 \\
(0.056)\end{array}$ \\
\hline Constant & $\begin{array}{c}0.869^{* * *} \\
(0.037)\end{array}$ & $\begin{array}{c}0.821^{* * * *} \\
(0.042)\end{array}$ & $\begin{array}{c}0.821^{* * *} \\
(0.042)\end{array}$ & $\begin{array}{c}0.869^{* * * *} \\
(0.037)\end{array}$ & $\begin{array}{c}0.869^{* * * *} \\
(0.037)\end{array}$ & $\begin{array}{c}0.893^{* * * *} \\
(0.034)\end{array}$ & $\begin{array}{c}0.881^{* * * *} \\
(0.036)\end{array}$ \\
\hline Sample Size & 356 & 356 & 356 & 356 & 356 & 356 & 356 \\
\hline \multicolumn{8}{|l|}{ Difference Estimates } \\
\hline Inexp F - Inexp M & $\begin{array}{c}0.0499 \\
(0.0453)\end{array}$ & $\begin{array}{c}0.0434 \\
(0.0532)\end{array}$ & $\begin{array}{c}0.0164 \\
(0.0548)\end{array}$ & $\begin{array}{c}0.0499 \\
(0.0453)\end{array}$ & $\begin{array}{c}0.0138 \\
(0.0481)\end{array}$ & $\begin{array}{l}0.00804 \\
(0.0443)\end{array}$ & $\begin{array}{c}0.0380 \\
(0.0441)\end{array}$ \\
\hline $\operatorname{Exp} F-\operatorname{Exp} M$ & $\begin{array}{l}-0.00695 \\
(0.0500)\end{array}$ & $\begin{array}{l}0.00432 \\
(0.0534)\end{array}$ & $\begin{array}{l}-0.0431 \\
(0.0463)\end{array}$ & $\begin{array}{l}-0.0439 \\
(0.0489)\end{array}$ & $\begin{array}{c}0.0195 \\
(0.0445)\end{array}$ & $\begin{array}{c}-0.00386 \\
(0.0383)\end{array}$ & $\begin{array}{l}-0.00309 \\
(0.0345)\end{array}$ \\
\hline Exp F - Inexp F & $\begin{array}{l}-0.0343 \\
(0.0447)\end{array}$ & $\begin{array}{l}0.00693 \\
(0.0501)\end{array}$ & $\begin{array}{c}0.0468 \\
(0.0506)\end{array}$ & $\begin{array}{l}-0.0471 \\
(0.0461)\end{array}$ & $\begin{array}{c}0.0402 \\
(0.0432)\end{array}$ & $\begin{array}{c}0.0350 \\
(0.0399)\end{array}$ & $\begin{array}{c}0.0298 \\
(0.0362)\end{array}$ \\
\hline Exp M - Inexp M & $\begin{array}{c}0.0225 \\
(0.0505)\end{array}$ & $\begin{array}{c}0.0460 \\
(0.0563)\end{array}$ & $\begin{array}{l}0.106^{* *} \\
(0.0508)\end{array}$ & $\begin{array}{c}0.0466 \\
(0.0481)\end{array}$ & $\begin{array}{c}0.0346 \\
(0.0493)\end{array}$ & $\begin{array}{c}0.0469 \\
(0.0429)\end{array}$ & $\begin{array}{l}0.0709^{*} \\
(0.0427)\end{array}$ \\
\hline
\end{tabular}

Notes: Standard errors clustered at the GP level in parantheses. Significance: ${ }^{* * *} p<0.01 ;^{* *} p<$ $0.05 ;^{*} p<0.1$. Outcomes are 1 if the respondents said they "strongly disagree" or "disagree" with the following statements:

Column 1: It is ok for a shopkeeper to offer a politician a small gift to help keep the tax auditor away

Column 2: It is ok for a businessman to give a job in a family firm to a family member even though other applicants are more qualified

Column 3: It is ok for a government employee to give a government job to a family member even though other applicants are more qualified

Column 4: It is ok for a male politician to give a government job to a family member even though other applicants are more qualified

Column 5: It is ok for a female politician to give a government job to a family member even though other applicants are more qualified

Column 6: It is ok for a government employee to ask a school teacher for a small gift in exchange for approving his BPL card without proper documentation

Column 7: It is ok for a politician to ask a school teacher for a small gift in exchange for approving his BPL card without proper documentation 
Table A2: Trust in political institutions to do what is right. No additional controls included

\begin{tabular}{|c|c|c|c|c|}
\hline & $\begin{array}{l}\text { GP } \\
(1)\end{array}$ & $\begin{array}{c}\text { Gram Pradhan } \\
(2)\end{array}$ & $\begin{array}{c}\text { Local MLA } \\
\text { (3) }\end{array}$ & $\begin{array}{c}\text { Local MP } \\
(4)\end{array}$ \\
\hline Exp & $\begin{array}{l}-0.025 \\
(0.037)\end{array}$ & $\begin{array}{c}-0.097^{* *} \\
(0.045)\end{array}$ & $\begin{array}{l}-0.029 \\
(0.076)\end{array}$ & $\begin{array}{l}-0.055 \\
(0.077)\end{array}$ \\
\hline Female & $\begin{array}{l}-0.015 \\
(0.033)\end{array}$ & $\begin{array}{c}0.021 \\
(0.028)\end{array}$ & $\begin{array}{c}0.054 \\
(0.069)\end{array}$ & $\begin{array}{c}0.073 \\
(0.073)\end{array}$ \\
\hline Exp $\times$ Female & $\begin{array}{c}0.024 \\
(0.052)\end{array}$ & $\begin{array}{c}0.047 \\
(0.057)\end{array}$ & $\begin{array}{l}-0.105 \\
(0.104)\end{array}$ & $\begin{array}{l}-0.059 \\
(0.107)\end{array}$ \\
\hline Constant & $\begin{array}{c}0.952^{* * *} \\
(0.023)\end{array}$ & $\begin{array}{c}0.952^{* * *} \\
(0.023)\end{array}$ & $\begin{array}{c}0.631^{* * *} \\
(0.053)\end{array}$ & $\begin{array}{c}0.476^{* * *} \\
(0.055)\end{array}$ \\
\hline Sample Size & 356 & 356 & 356 & 356 \\
\hline \multicolumn{5}{|l|}{ Difference Estimates } \\
\hline Inexp Female - Inexp Male & $\begin{array}{l}-0.0154 \\
(0.0329)\end{array}$ & $\begin{array}{c}0.0206 \\
(0.0280)\end{array}$ & $\begin{array}{c}0.0537 \\
(0.0691)\end{array}$ & $\begin{array}{c}0.0734 \\
(0.0725)\end{array}$ \\
\hline Exp Female - Exp Male & $\begin{array}{l}0.00819 \\
(0.0399)\end{array}$ & $\begin{array}{c}0.0677 \\
(0.0493)\end{array}$ & $\begin{array}{l}-0.0511 \\
(0.0783)\end{array}$ & $\begin{array}{c}0.0142 \\
(0.0785)\end{array}$ \\
\hline Exp Female - Inexp Female & $\begin{array}{c}-0.00104 \\
(0.0363)\end{array}$ & $\begin{array}{l}-0.0499 \\
(0.0341)\end{array}$ & $\begin{array}{l}-0.133^{*} \\
(0.0719)\end{array}$ & $\begin{array}{c}-0.114 \\
(0.0738)\end{array}$ \\
\hline Exp Male - Inexp Male & $\begin{array}{l}-0.0247 \\
(0.0369)\end{array}$ & $\begin{array}{c}-0.0970^{* *} \\
(0.0453)\end{array}$ & $\begin{array}{l}-0.0285 \\
(0.0756)\end{array}$ & $\begin{array}{l}-0.0545 \\
(0.0773)\end{array}$ \\
\hline
\end{tabular}

Notes: Standard errors clustered at the GP level. Significance: ${ }^{* * *} p<0.01 ;^{* *} p<$ $0.05 ;^{*} p<0.1$. Dependent variable $=1$ if responder reported trusting the relevant political institution "just about always" or "most of the time." 
Table A3: Behavior in experimental tasks. No additional controls included

\begin{tabular}{|c|c|c|c|c|c|}
\hline & $\begin{array}{c}\text { Reported } \\
\quad \# 6 \\
(1)\end{array}$ & $\begin{array}{l}\text { Dictator } \\
\text { Offer } \\
(2)\end{array}$ & $\begin{array}{l}\text { Trust } \\
\text { Offer } \\
(3)\end{array}$ & $\begin{array}{c}\text { Trust } \\
\text { Response } \\
(4)\end{array}$ & $\begin{array}{c}\text { Risk } \\
\text { Preference } \\
(5)\end{array}$ \\
\hline Exp & $\begin{array}{l}-0.278 \\
(0.636)\end{array}$ & $\begin{array}{c}1.094 \\
(2.826)\end{array}$ & $\begin{array}{l}-2.653 \\
(3.066)\end{array}$ & $\begin{array}{c}0.005 \\
(0.026)\end{array}$ & $\begin{array}{l}-1.413 \\
(5.130)\end{array}$ \\
\hline Female & $\begin{array}{l}-0.409 \\
(0.616)\end{array}$ & $\begin{array}{l}-1.014 \\
(3.151)\end{array}$ & $\begin{array}{c}0.598 \\
(3.461)\end{array}$ & $\begin{array}{l}-0.005 \\
(0.023)\end{array}$ & $\begin{array}{l}-6.387^{*} \\
(3.167)\end{array}$ \\
\hline Exp $\times$ Female & $\begin{array}{c}2.464^{* *} \\
(0.971)\end{array}$ & $\begin{array}{c}0.111 \\
(5.293)\end{array}$ & $\begin{array}{c}5.498 \\
(5.373)\end{array}$ & $\begin{array}{l}-0.021 \\
(0.036)\end{array}$ & $\begin{array}{c}10.959^{* *} \\
(5.319)\end{array}$ \\
\hline Constant & $\begin{array}{c}7.940 * * * \\
(0.577)\end{array}$ & $\begin{array}{c}60.833^{* * *} \\
(2.390)\end{array}$ & $\begin{array}{c}59.762^{* * *} \\
(2.467)\end{array}$ & $\begin{array}{c}0.426^{* * *} \\
(0.022)\end{array}$ & $\begin{array}{c}62.738^{* * *} \\
(2.657)\end{array}$ \\
\hline Sample Size & 356 & 356 & 356 & 356 & 356 \\
\hline \multicolumn{6}{|l|}{ Different Estimates } \\
\hline Inexp Female - Inexp Male & $\begin{array}{l}-0.409 \\
(0.616)\end{array}$ & $\begin{array}{l}-1.014 \\
(3.151)\end{array}$ & $\begin{array}{c}0.598 \\
(3.461)\end{array}$ & $\begin{array}{c}-0.00532 \\
(0.0233)\end{array}$ & $\begin{array}{c}-6.387^{* *} \\
(3.167)\end{array}$ \\
\hline Exp Female - Exp Male & $\begin{array}{c}2.055^{* *} \\
(0.876)\end{array}$ & $\begin{array}{l}-0.902 \\
(4.434)\end{array}$ & $\begin{array}{c}6.097 \\
(4.003)\end{array}$ & $\begin{array}{l}-0.0267 \\
(0.0262)\end{array}$ & $\begin{array}{c}4.572 \\
(5.468)\end{array}$ \\
\hline Exp Female - Inexp Female & $\begin{array}{c}2.186^{* *} \\
(0.835)\end{array}$ & $\begin{array}{c}1.206 \\
(4.508)\end{array}$ & $\begin{array}{c}2.845 \\
(3.065)\end{array}$ & $\begin{array}{l}-0.0163 \\
(0.0308)\end{array}$ & $\begin{array}{l}9.546^{* *} \\
(4.069)\end{array}$ \\
\hline Exp Male - Inexp Male & $\begin{array}{l}-0.278 \\
(0.636)\end{array}$ & $\begin{array}{c}1.094 \\
(2.826)\end{array}$ & $\begin{array}{l}-2.653 \\
(3.066)\end{array}$ & $\begin{array}{l}0.00506 \\
(0.0257)\end{array}$ & $\begin{array}{c}-1.413 \\
(5.130)\end{array}$ \\
\hline
\end{tabular}

Notes: Sample includes Inexperienced politicians without prior political experience and Experienced politicians. Standard errors clustered at the GP level. Significance: ${ }^{* * *} p<$ $0.01 ;^{* *} p<0.05 ;^{*} p<0.1$. 
Table A4: Aspiration for political office in the future

\begin{tabular}{|c|c|c|}
\hline & $\begin{array}{l}\text { Aspire Politics } \\
\text { (1) }\end{array}$ & $\begin{array}{l}\text { Aspire Politics } \\
\text { (2) }\end{array}$ \\
\hline Exp & $\begin{array}{c}-0.174^{* *} \\
(0.082)\end{array}$ & $\begin{array}{l}-0.159^{*} \\
(0.093)\end{array}$ \\
\hline Female & $\begin{array}{l}-0.047 \\
(0.059)\end{array}$ & $\begin{array}{c}0.013 \\
(0.062)\end{array}$ \\
\hline Exp $\times$ Female & $\begin{array}{l}-0.045 \\
(0.106)\end{array}$ & $\begin{array}{c}0.015 \\
(0.113)\end{array}$ \\
\hline Constant & $\begin{array}{c}1.175^{* * *} \\
(0.139)\end{array}$ & $\begin{array}{c}0.798^{* * *} \\
(0.053)\end{array}$ \\
\hline Controls & Yes & $\mathrm{No}$ \\
\hline Sample Size & 356 & 356 \\
\hline \multicolumn{3}{|l|}{ Difference Estimates } \\
\hline Inexp Female - Inexp Male & $\begin{array}{l}-0.0475 \\
(0.0585)\end{array}$ & $\begin{array}{c}0.0132 \\
(0.0616)\end{array}$ \\
\hline Exp Female - Exp Male & $\begin{array}{l}-0.0921 \\
(0.0739)\end{array}$ & $\begin{array}{c}0.0281 \\
(0.0764)\end{array}$ \\
\hline Exp Female - Inexp Female & $\begin{array}{c}-0.219^{* * *} \\
(0.0709)\end{array}$ & $\begin{array}{l}-0.144^{* *} \\
(0.0727)\end{array}$ \\
\hline Exp Male - Inexp Male & $\begin{array}{r}-0.174^{* *} \\
(0.0819)\end{array}$ & $\begin{array}{l}-0.159^{*} \\
(0.0927)\end{array}$ \\
\hline
\end{tabular}

Notes: Dependent variable in regressions is a dummy variable $=1$ if the individual responds "Yes" to the question: do you want to run for political office in the future? The controls included in column 1 are: age, years of schooling, religion/caste, land owned, political network and primary occupation. Standard errors are clustered at the GP level. Significance: ${ }^{* * *} p<0.01 ;^{* *} p<0.05 ;^{*} p<0.1$. 
Table B1: Attitudes towards Dishonest Behavior. Including Controls. Full Set of Results

\begin{tabular}{|c|c|c|c|c|c|c|c|}
\hline & (1) & $(2)$ & (3) & $(4)$ & $(5)$ & (6) & (7) \\
\hline Exp & $\begin{array}{c}0.074 \\
(0.056)\end{array}$ & $\begin{array}{l}0.101^{*} \\
(0.060)\end{array}$ & $\begin{array}{c}0.149^{* * *} \\
(0.056)\end{array}$ & $\begin{array}{l}0.096^{*} \\
(0.054)\end{array}$ & $\begin{array}{l}0.090^{*} \\
(0.052)\end{array}$ & $\begin{array}{l}0.088^{*} \\
(0.051)\end{array}$ & $\begin{array}{c}0.112^{* *} \\
(0.050)\end{array}$ \\
\hline Female & $\begin{array}{c}0.060 \\
(0.065)\end{array}$ & $\begin{array}{c}0.007 \\
(0.073)\end{array}$ & $\begin{array}{c}0.019 \\
(0.071)\end{array}$ & $\begin{array}{c}0.026 \\
(0.062)\end{array}$ & $\begin{array}{c}0.063 \\
(0.067)\end{array}$ & $\begin{array}{c}0.019 \\
(0.062)\end{array}$ & $\begin{array}{c}0.004 \\
(0.058)\end{array}$ \\
\hline Exp $\times$ Female & $\begin{array}{l}-0.056 \\
(0.068)\end{array}$ & $\begin{array}{l}-0.036 \\
(0.075)\end{array}$ & $\begin{array}{l}-0.065 \\
(0.071)\end{array}$ & $\begin{array}{l}-0.083 \\
(0.066)\end{array}$ & $\begin{array}{c}-0.002 \\
(0.063)\end{array}$ & $\begin{array}{l}-0.014 \\
(0.061)\end{array}$ & $\begin{array}{l}-0.040 \\
(0.057)\end{array}$ \\
\hline Years of educ. $(6-10)$ & $\begin{array}{l}0.153^{*} \\
(0.080)\end{array}$ & $\begin{array}{c}0.121 \\
(0.082)\end{array}$ & $\begin{array}{c}0.026 \\
(0.074)\end{array}$ & $\begin{array}{c}0.109 \\
(0.076)\end{array}$ & $\begin{array}{c}0.038 \\
(0.068)\end{array}$ & $\begin{array}{c}0.000 \\
(0.059)\end{array}$ & $\begin{array}{c}0.031 \\
(0.060)\end{array}$ \\
\hline Years of educ. $(>10)$ & $\begin{array}{r}0.189^{* *} \\
(0.080)\end{array}$ & $\begin{array}{c}0.134 \\
(0.083)\end{array}$ & $\begin{array}{c}0.080 \\
(0.074)\end{array}$ & $\begin{array}{c}0.152^{* *} \\
(0.075)\end{array}$ & $\begin{array}{c}0.080 \\
(0.070)\end{array}$ & $\begin{array}{c}0.054 \\
(0.057)\end{array}$ & $\begin{array}{c}0.027 \\
(0.061)\end{array}$ \\
\hline Age & $\begin{array}{c}0.004^{* *} \\
(0.002)\end{array}$ & $\begin{array}{l}0.004^{*} \\
(0.002)\end{array}$ & $\begin{array}{c}0.003 \\
(0.002)\end{array}$ & $\begin{array}{c}0.002 \\
(0.002)\end{array}$ & $\begin{array}{l}0.004^{*} \\
(0.002)\end{array}$ & $\begin{array}{c}0.001 \\
(0.002)\end{array}$ & $\begin{array}{c}0.002 \\
(0.001)\end{array}$ \\
\hline Hindu General Cat. & $\begin{array}{c}0.015 \\
(0.058)\end{array}$ & $\begin{array}{l}-0.016 \\
(0.062)\end{array}$ & $\begin{array}{c}0.031 \\
(0.053)\end{array}$ & $\begin{array}{c}0.019 \\
(0.052)\end{array}$ & $\begin{array}{l}-0.076 \\
(0.058)\end{array}$ & $\begin{array}{c}0.025 \\
(0.050)\end{array}$ & $\begin{array}{c}0.043 \\
(0.042)\end{array}$ \\
\hline Hindu OBC & $\begin{array}{c}0.040 \\
(0.046)\end{array}$ & $\begin{array}{l}-0.011 \\
(0.060)\end{array}$ & $\begin{array}{l}-0.092 \\
(0.069)\end{array}$ & $\begin{array}{l}-0.004 \\
(0.053)\end{array}$ & $\begin{array}{l}-0.085 \\
(0.059)\end{array}$ & $\begin{array}{c}0.005 \\
(0.050)\end{array}$ & $\begin{array}{c}0.036 \\
(0.044)\end{array}$ \\
\hline Hindu SC/ST & $\begin{array}{c}0.032 \\
(0.041)\end{array}$ & $\begin{array}{c}0.020 \\
(0.043)\end{array}$ & $\begin{array}{l}-0.027 \\
(0.045)\end{array}$ & $\begin{array}{l}-0.006 \\
(0.040)\end{array}$ & $\begin{array}{l}-0.038 \\
(0.040)\end{array}$ & $\begin{array}{c}0.030 \\
(0.035)\end{array}$ & $\begin{array}{c}0.050 \\
(0.036)\end{array}$ \\
\hline Land owned (katha) & $\begin{array}{l}-0.000 \\
(0.000)\end{array}$ & $\begin{array}{c}0.000 \\
(0.000)\end{array}$ & $\begin{array}{l}-0.000 \\
(0.000)\end{array}$ & $\begin{array}{l}-0.000 \\
(0.000)\end{array}$ & $\begin{array}{l}-0.000 \\
(0.000)\end{array}$ & $\begin{array}{c}0.000 \\
(0.000)\end{array}$ & $\begin{array}{l}-0.000 \\
(0.000)\end{array}$ \\
\hline Self-empl. farming & $\begin{array}{l}0.097^{*} \\
(0.057)\end{array}$ & $\begin{array}{c}0.041 \\
(0.063)\end{array}$ & $\begin{array}{c}0.084 \\
(0.056)\end{array}$ & $\begin{array}{c}0.061 \\
(0.046)\end{array}$ & $\begin{array}{l}0.096^{*} \\
(0.054)\end{array}$ & $\begin{array}{l}0.087^{*} \\
(0.047)\end{array}$ & $\begin{array}{c}0.049 \\
(0.041)\end{array}$ \\
\hline Self-empl. non-farming & $\begin{array}{c}0.080 \\
(0.054)\end{array}$ & $\begin{array}{l}-0.008 \\
(0.061)\end{array}$ & $\begin{array}{c}0.039 \\
(0.055)\end{array}$ & $\begin{array}{l}-0.015 \\
(0.050)\end{array}$ & $\begin{array}{c}0.078 \\
(0.051)\end{array}$ & $\begin{array}{c}0.061 \\
(0.048)\end{array}$ & $\begin{array}{c}0.002 \\
(0.046)\end{array}$ \\
\hline Domestic Duties & $\begin{array}{l}0.093^{*} \\
(0.047)\end{array}$ & $\begin{array}{l}0.101^{*} \\
(0.055)\end{array}$ & $\begin{array}{l}0.098^{*} \\
(0.058)\end{array}$ & $\begin{array}{c}0.060 \\
(0.048)\end{array}$ & $\begin{array}{c}0.062 \\
(0.051)\end{array}$ & $\begin{array}{c}0.069 \\
(0.046)\end{array}$ & $\begin{array}{c}0.064 \\
(0.041)\end{array}$ \\
\hline Leaders in family & $\begin{array}{c}0.029^{* *} \\
(0.014)\end{array}$ & $\begin{array}{c}0.003 \\
(0.019)\end{array}$ & $\begin{array}{c}0.009 \\
(0.017)\end{array}$ & $\begin{array}{l}0.025^{*} \\
(0.013)\end{array}$ & $\begin{array}{l}-0.009 \\
(0.027)\end{array}$ & $\begin{array}{c}0.037^{* * *} \\
(0.012)\end{array}$ & $\begin{array}{c}0.030 * * * \\
(0.011)\end{array}$ \\
\hline No leadership exp. & $\begin{array}{c}0.179 * * * \\
(0.047)\end{array}$ & $\begin{array}{c}0.176^{* * *} \\
(0.049)\end{array}$ & $\begin{array}{c}0.135^{* * *} \\
(0.046)\end{array}$ & $\begin{array}{c}0.165^{* * *} \\
(0.047)\end{array}$ & $\begin{array}{c}0.142^{* * *} \\
(0.046)\end{array}$ & $\begin{array}{c}0.117^{* * *} \\
(0.042)\end{array}$ & $\begin{array}{c}0.120^{* * *} \\
(0.041)\end{array}$ \\
\hline Constant & $\begin{array}{c}0.325^{* *} \\
(0.149)\end{array}$ & $\begin{array}{c}0.384^{* *} \\
(0.156)\end{array}$ & $\begin{array}{c}0.500^{* * *} * \\
(0.150)\end{array}$ & $\begin{array}{c}0.504^{* * *} \\
(0.139)\end{array}$ & $\begin{array}{c}0.509^{* * *} \\
(0.145)\end{array}$ & $\begin{array}{c}0.634^{* * *} * \\
(0.121)\end{array}$ & $\begin{array}{c}0.643^{* * *} \\
(0.116)\end{array}$ \\
\hline Sample Size & 356 & 356 & 356 & 356 & 356 & 356 & 356 \\
\hline
\end{tabular}

Notes: Standard errors clustered at the GP level. Significance: ${ }^{* * *} p<0.01$ *** $^{* *}<0.05$; $^{*} p<0.1$. Outcomes are 1 if the respondents strongly disagree with statement:

Column 1: It is ok for a shopkeeper to offer a politician a small gift to help keep the tax auditor away Column 2: It is ok for a businessman to give a job in a family firm to a family member even though other applicants are more qualified

Column 3: It is ok for a government employee to give a government job to a family member even though other applicants are more qualified

Column 4: It is ok for a male politician to give a government job to a family member even though other applicants are more qualified

Column 5: It is ok for a female politician to give a government job to a family member even though other applicants are more qualified

Column 6: It is ok for a government employee to ask a school teacher for a small gift in exchange for approving his BPL card without proper documentation

Column 7: It is ok for a politician to ask a school teacher for a small gift in exchange for approving his $B P L$ card without proper documentation 
Table B2: Trust in political institutions doing what is right. Full set of results

\begin{tabular}{|c|c|c|c|c|}
\hline & $\begin{array}{l}\text { GP } \\
(1)\end{array}$ & $\begin{array}{c}\text { Gram Pradhan } \\
(2)\end{array}$ & $\begin{array}{c}\text { Local MLA } \\
\text { (3) }\end{array}$ & $\begin{array}{l}\text { Local MP } \\
\quad(4)\end{array}$ \\
\hline Exp & $\begin{array}{l}-0.032 \\
(0.045)\end{array}$ & $\begin{array}{l}-0.041 \\
(0.048)\end{array}$ & $\begin{array}{l}-0.045 \\
(0.084)\end{array}$ & $\begin{array}{l}-0.082 \\
(0.093)\end{array}$ \\
\hline Female & $\begin{array}{l}-0.016 \\
(0.050)\end{array}$ & $\begin{array}{c}0.037 \\
(0.043)\end{array}$ & $\begin{array}{l}-0.040 \\
(0.087)\end{array}$ & $\begin{array}{c}0.053 \\
(0.098)\end{array}$ \\
\hline Exp $\times$ Female & $\begin{array}{c}0.008 \\
(0.052)\end{array}$ & $\begin{array}{c}0.037 \\
(0.054)\end{array}$ & $\begin{array}{c}-0.107 \\
(0.103)\end{array}$ & $\begin{array}{l}-0.048 \\
(0.110)\end{array}$ \\
\hline Years of educ. $(6-10)$ & $\begin{array}{c}0.010 \\
(0.051)\end{array}$ & $\begin{array}{l}-0.026 \\
(0.040)\end{array}$ & $\begin{array}{l}-0.159^{*} \\
(0.087)\end{array}$ & $\begin{array}{l}-0.018 \\
(0.099)\end{array}$ \\
\hline Years of educ. $(>10)$ & $\begin{array}{c}0.027 \\
(0.054)\end{array}$ & $\begin{array}{c}-0.022 \\
(0.040)\end{array}$ & $\begin{array}{c}-0.084 \\
(0.092)\end{array}$ & $\begin{array}{c}0.093 \\
(0.104)\end{array}$ \\
\hline Age & $\begin{array}{l}-0.000 \\
(0.002)\end{array}$ & $\begin{array}{l}-0.001 \\
(0.002)\end{array}$ & $\begin{array}{c}0.001 \\
(0.003)\end{array}$ & $\begin{array}{c}0.002 \\
(0.003)\end{array}$ \\
\hline Hindu General Category & $\begin{array}{c}0.003 \\
(0.039)\end{array}$ & $\begin{array}{l}-0.072 \\
(0.058)\end{array}$ & $\begin{array}{c}0.133 \\
(0.084)\end{array}$ & $\begin{array}{l}-0.013 \\
(0.091)\end{array}$ \\
\hline Hindu OBC & $\begin{array}{l}-0.043 \\
(0.054)\end{array}$ & $\begin{array}{l}-0.033 \\
(0.052)\end{array}$ & $\begin{array}{l}-0.137 \\
(0.092)\end{array}$ & $\begin{array}{l}-0.148 \\
(0.095)\end{array}$ \\
\hline Hindu SC/ST & $\begin{array}{l}-0.002 \\
(0.029)\end{array}$ & $\begin{array}{c}0.021 \\
(0.028)\end{array}$ & $\begin{array}{c}0.031 \\
(0.061)\end{array}$ & $\begin{array}{l}-0.032 \\
(0.065)\end{array}$ \\
\hline Land owned (katha) & $\begin{array}{l}-0.000 \\
(0.000)\end{array}$ & $\begin{array}{l}-0.000 \\
(0.000)\end{array}$ & $\begin{array}{l}-0.000 \\
(0.000)\end{array}$ & $\begin{array}{l}-0.000 \\
(0.000)\end{array}$ \\
\hline Occupation: Self-employed, farming & $\begin{array}{c}0.059 \\
(0.050)\end{array}$ & $\begin{array}{c}0.039 \\
(0.055)\end{array}$ & $\begin{array}{l}-0.112 \\
(0.093)\end{array}$ & $\begin{array}{l}-0.009 \\
(0.098)\end{array}$ \\
\hline Occupation: Self-employed, non-farming & $\begin{array}{c}0.061 \\
(0.045)\end{array}$ & $\begin{array}{c}0.026 \\
(0.042)\end{array}$ & $\begin{array}{l}-0.094 \\
(0.077)\end{array}$ & $\begin{array}{l}-0.045 \\
(0.083)\end{array}$ \\
\hline Occupation: Domestic duties & $\begin{array}{c}0.062 \\
(0.042)\end{array}$ & $\begin{array}{l}-0.010 \\
(0.034)\end{array}$ & $\begin{array}{c}0.054 \\
(0.074)\end{array}$ & $\begin{array}{c}0.058 \\
(0.078)\end{array}$ \\
\hline Leaders in family & $\begin{array}{c}0.001 \\
(0.014)\end{array}$ & $\begin{array}{c}0.006 \\
(0.013)\end{array}$ & $\begin{array}{c}-0.121^{* * *} \\
(0.028)\end{array}$ & $\begin{array}{c}-0.095^{* * *} \\
(0.028)\end{array}$ \\
\hline No leadership experience & $\begin{array}{c}-0.022 \\
(0.040)\end{array}$ & $\begin{array}{c}0.076 \\
(0.047)\end{array}$ & $\begin{array}{c}0.004 \\
(0.068)\end{array}$ & $\begin{array}{c}0.013 \\
(0.073)\end{array}$ \\
\hline Constant & $\begin{array}{c}0.948^{* * *} \\
(0.101)\end{array}$ & $\begin{array}{c}0.936^{* * *} \\
(0.093)\end{array}$ & $\begin{array}{c}0.808^{* * *} \\
(0.186)\end{array}$ & $\begin{array}{c}0.426^{* *} \\
(0.200)\end{array}$ \\
\hline Sample Size & 356 & 356 & 356 & 356 \\
\hline
\end{tabular}

Notes: Standard errors clustered at the GP level. Significance: ${ }^{* * *} p<0.01 ;^{* *} p<0.05 ;^{*} p<0.1$. Dependent variable $=1$ if responder reports trusting the relevant political institution just about always or most of the time. 
Table B3: Behavior in the other experimental tasks. Full set of results

\begin{tabular}{|c|c|c|c|c|c|}
\hline & $\begin{array}{l}\text { Reported } \\
\text { \# sixes } \\
\quad(1)\end{array}$ & $\begin{array}{l}\text { Dictator } \\
\text { Offer } \\
(2)\end{array}$ & $\begin{array}{l}\text { Trust } \\
\text { Offer } \\
(3)\end{array}$ & $\begin{array}{c}\text { Trust } \\
\text { Response } \\
\quad(4)\end{array}$ & $\begin{array}{c}\text { Risk } \\
\text { Preference } \\
(5)\end{array}$ \\
\hline $\operatorname{Exp}$ & $\begin{array}{c}0.526 \\
(0.926)\end{array}$ & $\begin{array}{c}1.473 \\
(4.092)\end{array}$ & $\begin{array}{l}-1.196 \\
(4.802)\end{array}$ & $\begin{array}{c}0.021 \\
(0.029)\end{array}$ & $\begin{array}{l}-1.453 \\
(5.362)\end{array}$ \\
\hline Female & $\begin{array}{l}-1.085 \\
(0.998)\end{array}$ & $\begin{array}{l}-0.342 \\
(4.530)\end{array}$ & $\begin{array}{l}-3.189 \\
(5.651)\end{array}$ & $\begin{array}{c}0.016 \\
(0.031)\end{array}$ & $\begin{array}{c}-7.398^{*} \\
(4.142)\end{array}$ \\
\hline Exp $\times$ Female & $\begin{array}{l}2.114^{*} \\
(1.125)\end{array}$ & $\begin{array}{l}-1.024 \\
(5.299)\end{array}$ & $\begin{array}{c}4.203 \\
(5.650)\end{array}$ & $\begin{array}{l}-0.009 \\
(0.035)\end{array}$ & $\begin{array}{l}9.748^{*} \\
(5.578)\end{array}$ \\
\hline Years of education $(6-10)$ & $\begin{array}{l}-0.883 \\
(0.871)\end{array}$ & $\begin{array}{c}0.683 \\
(4.275)\end{array}$ & $\begin{array}{c}1.710 \\
(3.340)\end{array}$ & $\begin{array}{l}-0.016 \\
(0.037)\end{array}$ & $\begin{array}{l}-6.426 \\
(5.910)\end{array}$ \\
\hline Years of education $(>10)$ & $\begin{array}{l}-0.548 \\
(0.891)\end{array}$ & $\begin{array}{l}-0.975 \\
(3.774)\end{array}$ & $\begin{array}{l}-1.359 \\
(3.957)\end{array}$ & $\begin{array}{l}-0.008 \\
(0.041)\end{array}$ & $\begin{array}{l}-3.265 \\
(7.028)\end{array}$ \\
\hline Age & $\begin{array}{c}-0.076^{* *} \\
(0.031)\end{array}$ & $\begin{array}{l}-0.050 \\
(0.119)\end{array}$ & $\begin{array}{c}-0.305^{*} \\
(0.159)\end{array}$ & $\begin{array}{c}0.003^{* * *} \\
(0.001)\end{array}$ & $\begin{array}{l}-0.192 \\
(0.200)\end{array}$ \\
\hline Hindu General Category & $\begin{array}{l}-1.221 \\
(0.954)\end{array}$ & $\begin{array}{c}2.306 \\
(4.621)\end{array}$ & $\begin{array}{l}-0.480 \\
(4.220)\end{array}$ & $\begin{array}{c}0.018 \\
(0.034)\end{array}$ & $\begin{array}{c}-16.152^{* * *} \\
(5.808)\end{array}$ \\
\hline Hindu OBC & $\begin{array}{l}-1.114 \\
(0.889)\end{array}$ & $\begin{array}{l}-1.931 \\
(5.006)\end{array}$ & $\begin{array}{c}1.521 \\
(3.763)\end{array}$ & $\begin{array}{l}-0.039 \\
(0.028)\end{array}$ & $\begin{array}{l}-6.800 \\
(5.070)\end{array}$ \\
\hline Hindu SC/ST & $\begin{array}{l}-0.130 \\
(0.910)\end{array}$ & $\begin{array}{c}2.426 \\
(2.555)\end{array}$ & $\begin{array}{c}0.080 \\
(2.225)\end{array}$ & $\begin{array}{l}-0.015 \\
(0.017)\end{array}$ & $\begin{array}{c}0.293 \\
(2.957)\end{array}$ \\
\hline Land owned (Katha) & $\begin{array}{c}-0.007^{*} \\
(0.004)\end{array}$ & $\begin{array}{c}0.007 \\
(0.016)\end{array}$ & $\begin{array}{c}0.004 \\
(0.022)\end{array}$ & $\begin{array}{l}-0.000 \\
(0.000)\end{array}$ & $\begin{array}{l}-0.029 \\
(0.029)\end{array}$ \\
\hline Self-employed, farming & $\begin{array}{c}1.648 \\
(1.128)\end{array}$ & $\begin{array}{l}-3.952 \\
(6.005)\end{array}$ & $\begin{array}{l}-1.406 \\
(5.420)\end{array}$ & $\begin{array}{c}0.046 \\
(0.044)\end{array}$ & $\begin{array}{c}6.648 \\
(5.179)\end{array}$ \\
\hline Self-employed, non-farming & $\begin{array}{c}0.633 \\
(0.960)\end{array}$ & $\begin{array}{c}2.617 \\
(4.210)\end{array}$ & $\begin{array}{c}0.332 \\
(5.237)\end{array}$ & $\begin{array}{l}-0.023 \\
(0.037)\end{array}$ & $\begin{array}{c}1.559 \\
(4.706)\end{array}$ \\
\hline Domestic duties & $\begin{array}{c}1.354 \\
(0.799)\end{array}$ & $\begin{array}{l}-1.589 \\
(3.428)\end{array}$ & $\begin{array}{c}2.583 \\
(3.327)\end{array}$ & $\begin{array}{l}-0.014 \\
(0.026)\end{array}$ & $\begin{array}{c}4.545 \\
(4.531)\end{array}$ \\
\hline Leaders in family & $\begin{array}{c}-0.832^{* * *} \\
(0.271)\end{array}$ & $\begin{array}{l}-2.639 \\
(1.590)\end{array}$ & $\begin{array}{l}-1.144 \\
(2.052)\end{array}$ & $\begin{array}{c}0.009 \\
(0.011)\end{array}$ & $\begin{array}{l}-1.815 \\
(1.532)\end{array}$ \\
\hline No leadership experience & $\begin{array}{c}0.684 \\
(0.990)\end{array}$ & $\begin{array}{l}-1.719 \\
(3.849)\end{array}$ & $\begin{array}{l}-1.769 \\
(4.234)\end{array}$ & $\begin{array}{c}0.075^{* * *} \\
(0.025)\end{array}$ & $\begin{array}{l}-3.489 \\
(3.455)\end{array}$ \\
\hline Constant & $\begin{array}{c}11.343^{* * *} \\
(2.343)\end{array}$ & $\begin{array}{c}64.174^{* * *} \\
(7.019)\end{array}$ & $\begin{array}{c}74.235^{* * *} \\
(9.234)\end{array}$ & $\begin{array}{c}0.263^{* * *} \\
(0.069)\end{array}$ & $\begin{array}{c}79.897^{* * *} \\
(10.113)\end{array}$ \\
\hline Sample Size & 356 & 356 & 356 & 356 & 356 \\
\hline
\end{tabular}

Notes: Sample includes Inexperienced politicians without prior political experience and Experienced politicians. Regressions in column 3 control for offer in dictator game and proportion invested in the risky asset in the investment game. Regressions in column 4 control for offer in trust game. Standard errors clustered at the GP level. Significance: ${ }^{* * *} p<0.01 ;^{* *} p<0.05 ;^{*} p<0.1$. 